$1-19-2021$

\title{
COVID-19, the Shadow Pandemic, and Access to Justice for Survivors of Domestic Violence
}

Jennifer Koshan

Faculty of Law, University of Calgary

Janet Mosher

Osgoode Hall Law School of York University

Wanda Wiegers

College of Law, University of Saskatchewan

Follow this and additional works at: https://digitalcommons.osgoode.yorku.ca/ohlj

Part of the Law Commons

Article

\section{Citation Information}

Koshan, Jennifer; Mosher, Janet; and Wiegers, Wanda. "COVID-19, the Shadow Pandemic, and Access to Justice for Survivors of Domestic Violence." Osgoode Hall Law Journal 57.3 (2021) : 739-799.

https://digitalcommons.osgoode.yorku.ca/ohlj/vol57/iss3/8

This Article is brought to you for free and open access by the Journals at Osgoode Digital Commons. It has been accepted for inclusion in Osgoode Hall Law Journal by an authorized editor of Osgoode Digital Commons. 


\title{
COVID-19, the Shadow Pandemic, and Access to Justice for Survivors of Domestic Violence
}

\author{
Abstract \\ The COVID-19 pandemic has co-existed alongside a far less visible "shadow pandemic" of violence \\ against women, with COVID-19 impacting the number and complexity of domestic violence cases and \\ enabling new tactics for coercive control. This article provides a preliminary assessment of the extent to \\ which Canada's responses to the COVID-19 pandemic have prioritized the safety of women and children, \\ with a focus on the courts and women's access to justice. We examine court directives and judicial \\ decisions triaging which cases would be heard as "urgent," as well as courts' decisions on the merits in \\ cases involving domestic violence and COVID-19, spanning the areas of family, child welfare, criminal law, \\ and civil protection orders. In the sixty-seven reported decisions in our sample, we find very little \\ awareness overall of the heightened risks for survivors during COVID-19, in keeping with the pre- \\ pandemic tendency of decision makers to focus on incident-based physical violence instead of patterns \\ of coercive control. Our analysis also suggests that survivors' ability to prove domestic violence and \\ secure court orders that would help to ensure their safety was hampered not only by procedural \\ complexity but also by the reduced availability of a range of services-health, counselling, housing, and \\ supervised access centres, for example-as a result of COVID-19. The cases further reveal significant \\ differences in judicial interpretation of the risks of COVID-19 relative to the risks of domestic violence, \\ often depending on the area of law in question. This again aligns with observations of the judicial \\ treatment of domestic violence prior to the COVID-19 pandemic, with different and sometimes conflicting \\ norms and assumptions prevailing in different legal contexts. We conclude that despite some positive \\ government responses and judicial decisions, COVID-19 has further exposed many of the gaps in \\ knowledge about domestic violence and in the supports and resources necessary to make women and \\ children safe that long pre-dated COVID-19. In addressing the ongoing pandemic of violence against \\ women, we offer some suggestions of measures to improve access to justice during this and future \\ disasters.
}




\title{
COVID-19, the Shadow Pandemic, and Access to Justice for Survivors of Domestic Violence
}

\author{
JENNIFER KOSHAN, ${ }^{*}$ JANET MOSHER, ${ }^{+}$ \\ AND WANDA WIEGERS
}

The COVID-19 pandemic has co-existed alongside a far less visible "shadow pandemic" of violence against women, with COVID-19 impacting the number and complexity of domestic violence cases and enabling new tactics for coercive control. This article provides a preliminary assessment of the extent to which Canada's responses to the COVID-19 pandemic have prioritized the safety of women and children, with a focus on the courts and women's access to justice. We examine court directives and judicial decisions triaging which cases would be heard as "urgent," as well as courts' decisions on the merits in cases involving domestic violence and COVID-19, spanning the areas of family, child welfare, criminal law, and civil protection orders. In the sixty-seven reported decisions in our sample, we find very little awareness overall of the heightened risks for survivors during COVID-19, in keeping with the pre-pandemic tendency of decision makers to focus on incident-based physical violence instead of patterns of coercive control. Our analysis also suggests that survivors' ability to prove domestic violence and secure court orders that would help to ensure their safety was hampered not only by procedural complexity but also by the reduced availability of a range of services-health, counselling, housing, and supervised access centres, for example-as a result of COVID-19. The cases further reveal significant differences in judicial interpretation of the risks of COVID-19 relative to the risks of domestic violence, often depending on the area of law in question. This again aligns with observations of the judicial treatment of domestic violence prior to the COVID-19 pandemic, with different and sometimes conflicting

Professor, Faculty of Law, University of Calgary.

$+\quad$ Associate Professor, Osgoode Hall Law School, York University.

$\ddagger \quad$ Professor, College of Law, University of Saskatchewan. Thanks to our research assistants Madyson Schmidt (University of Calgary, Faculty of Law) and Samara Rotstein (Osgoode Hall Law School). We gratefully acknowledge funding from the Social Sciences and Humanities Research Council for our research on domestic violence and access to justice. 
norms and assumptions prevailing in different legal contexts. We conclude that despite some positive government responses and judicial decisions, COVID-19 has further exposed many of the gaps in knowledge about domestic violence and in the supports and resources necessary to make women and children safe that long pre-dated COVID-19. In addressing the ongoing pandemic of violence against women, we offer some suggestions of measures to improve access to justice during this and future disasters.

I. COVID-19 AND THE SHADOW PANDEMIC OF DOMESTIC VIOLENCE ...................................... 746

A. The Emerging Data on COVID-19 and Domestic Violence ................................................ 746

B. Pathways Linking COVID-19 and Domestic Violence................................................ 752

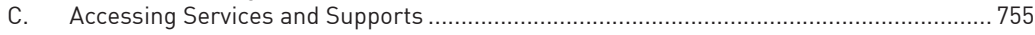

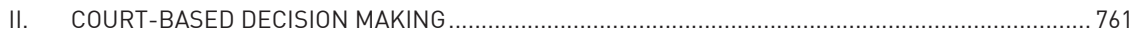

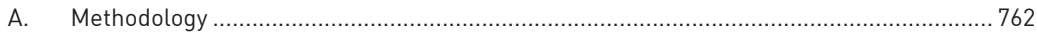

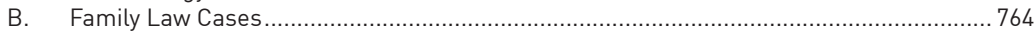

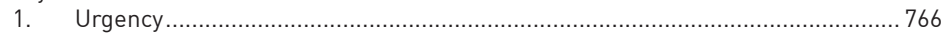

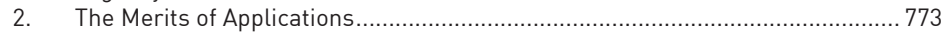

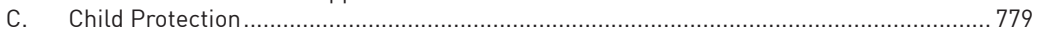

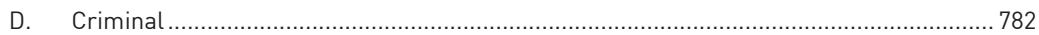

E. Emergency Protection Orders and Restraining Orders ........................................... 790

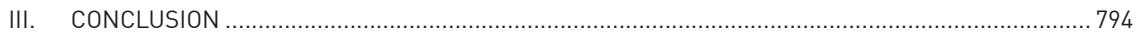

ALONGSIDE THE HIGHLY VISIBLE COVID-19 pandemic exists a "shadow pandemic" of violence against women. While the term "pandemic" is usually ascribed to a global outbreak caused by a strain of a virus previously unknown to be circulating in the human population, the United Nations Entity for Gender Equality and Empowerment of Women (UN Women) used the term "pandemic" as early as 2014 to capture the global pervasiveness of violence against women and girls and the high rates of associated morbidity and mortality. ${ }^{1}$ There are then, two global pandemics occurring simultaneously: one, COVID-19, highly visible and receiving significant public attention and resources, and the other, violence against women, its prevalence and harms far less visible and efforts to address it under-resourced.

These dual pandemics not only co-exist but interact. As Phumzile Mlambo-Ngcuka, the Executive Director of UN Women, made clear when announcing the "shadow pandemic" public awareness campaign, "[e]ven before the [COVID-19] pandemic, violence against women was one of the most

1. United Nations, "UN sounds alarm to end 'global pandemic' of violence against women" (25 November 2014), online: UN News <news.un.org/en/story/2014/11/484692> [perma. cc/FX46-H7WH]. For similar remarks made in 2016, see United Nations, "Invest and mobilize to end violence against women," online: UN Women <www.unwomen.org/en/news/ in-focus/end-violence-against-women/2016> [perma.cc/6WNZ-AVY6]. 
widespread violations of human rights. Since lockdown restrictions, domestic violence has multiplied, spreading across the world in a shadow pandemic." COVID-19 is generating not only new cases of domestic violence and other forms of gender-based violence, but more complex cases, and enabling new tactics of coercive control. ${ }^{3}$ Increases in domestic violence cases can be traced to the impact of the virus itself, as well as to societal responses to contain the virus, such as stay-at-home orders that lock women and children in homes with perpetrators, and the inaccessibility of services, including justice-sector services. Dubravka Šimonović, the UN Special Rapporteur on violence against women, has called on governments to "not allow the extraordinary circumstances and restrictive measures against COVID-19 to lead to the violation of women's

2. United Nations, "UN Women raises awareness of the shadow pandemic of violence against women during COVID-19” (27 May 2020), online: UN Women <www.unwomen.org/en/ news/stories/2020/5/press-release-the-shadow-pandemic-of-violence-against-women-duringcovid-19> [perma.cc/L8XP-6ECA] ["UN Women raises awareness"]. In an earlier statement, Mlambo-Ngcuka indicated that in the previous twelve months, globally 243 million women and girls (aged fifteen to forty-nine years old) had experienced physical or sexual abuse by an intimate partner. See United Nations, "Violence against women and girls: the shadow pandemic" (6 April 2020), online: UN Women <www.unwomen.org/en/news/stories/2020/4/ statement-ed-phumzile-violence-against-women-during-pandemic> [perma.cc/3VDS-ZLL6].

3. Throughout we use the term "domestic violence" (and also "intimate partner violence") to refer to violence perpetrated in the context of adult intimate relationships. While many typologies exist that seek to differentiate between types of domestic violence, there has been increasing recognition that domestic violence is often characterized by coercive control. Coercive control captures the multiple tactics, in addition to physical and sexual violence, used by abusers to control (often through micro-regulation), coerce (through threats and other means), and dominate their partners, instilling fear and depriving them of their liberty and autonomy. See e.g. Evan Stark, Coercive Control: How Men Entrap Women in Personal Life (Oxford University Press, 2009); Jane Wangmann, "Different Types of Intimate Partner Violence: An Exploration of the Literature” (Australian Domestic \& Family Violence Clearing House, 2011), online (pdf): <opus.lib.uts.edu.au/bitstream/10453/194 66/1/2010006199OK.pdf> [perma.cc/Y6J9-ZFMG]. Women are disproportionately the victims of domestic violence, but not all women are equally at risk. Gender intersects with other structures of oppression—colonialism, racism, heterosexism, ableism, xenophobia, et cetera - to both magnify risks and diminish access to resources and supports. While many legal actors calibrate the severity of harm based on discrete incidents of physical violence, women often report that the psychological harms engendered by ongoing coercive control are the most destructive and enduring. Many of the tactics associated with coercive control are also among the key risk factors for lethal violence. Coercive controlling violence also creates an environment of on-going stress and tension that can cause multiple harms to a child, including by impairing brain development; See Jane EM Callaghan et al, "Beyond 'Witnessing': Children's Experiences of Coercive Control in Domestic Violence and Abuse" (2018) 33 J Interpersonal Violence 1551; Lynn Hecht Schafran, "Domestic Violence, Developing Brains, and the Lifespan" (2014) 53 Judges' J 32. 
right to a life free from violence." ${ }^{4}$ Similarly, UN Secretary-General António Guterres, observing that "[m] any women under lockdown for [COVID-19] face violence where they should be safest: in their homes," urged "all governments to put women's safety first as they respond to the [COVID-19] pandemic."

In what follows, we offer a preliminary assessment of how Canada has fared in heeding this advice. Our assessment covers the period from 16 March 2020 (the date when many emergency orders went into effect across the country) to 1 June 2020. While no doubt action is required on many fronts to protect women's safety in the context of these dual pandemics, our focus is on the courts and women's access to justice. ${ }^{6}$ Our conceptualization of access to justice encompasses not only women's meaningful access to the courts and to legal assistance, but more substantively, whether decisions reflect an understanding and appropriate weighing of the risks of domestic violence, including the heightened risks during the COVID-19 pandemic. ${ }^{7}$ We were interested in court directives prioritizing which cases would be heard when physical courthouses and in-person hearings came to an abrupt halt, and in how judges were interpreting these directives. We were also interested to know whether judges (and counsel) appeared to be

4. United Nations Human Rights, "States must combat domestic violence in the context of COVID-19 lockdowns-UN rights expert" (27 March 2020), online: UN Human Rights News and Events <www.ohchr.org/EN/NewsEvents/Pages/DisplayNews.aspx?NewsID= 25749\&LangID=E $>$ [perma.cc/6MMK-JVGZ] [UNHR, "States must combat domestic violence"]; United Nations, "UN supporting 'trapped' domestic violence victims during COVID-19 pandemic" (12 June 2020), online: UN, Department of Global Communications $<$ www.un.org/en/coronavirus/un-supporting-\%E2\%80\%98trapped\%E2\%80\%99-domesticviolence-victims-during-covid-19-pandemic> [perma.cc/E28S-HAVZ] [UN, "Supporting victims during COVID-19"].

5. UN, "Supporting victims during COVID-19," supra note 4, citing António Guterres, "Peace is not just the absence of war. ... Today I appeal for peace in homes around the world. ..." (5 April 2020 at 21:30), online: Twitter <twitter.com/antonioguterres/ status/1246973397759819776> [perma.cc/7TTY-FRGP].

6. The impacts on women's access to justice and more particularly, whether courts are open and providing protection and decisions in cases of domestic violence, are one of a number of issues that the Special Rapporteur has requested information about from states and civil society organization. See United Nations Human Rights, "Call for Submissions: COVID-19 and the increase in domestic violence against women," online: UN Human Rights Special Rapporteur on Women <www.ohchr.org/EN/Issues/Women/SRWomen/Pages/call_covid19. aspx> [perma.cc/5NVQ-WUGX].

7. For a fuller discussion of access to justice in the context of domestic violence see Jennifer Koshan, Janet Mosher \& Wanda Wiegers, "The Costs of Justice in Domestic Violence Cases: Mapping Canadian Law and Policy," in Trevor Farrow \& Les Jacobs, eds, The Justice Crisis: The Cost and Value of Accessing Law (UBC Press, 2020), online: <ssrn.com/abstract= 3598277> [perma.cc/4752-323H] [Koshan, Mosher \& Wiegers, "The Costs of Justice"]. 
cognizant of the heightened risks of domestic violence and the COVID-19 related tactics being used by abusive partners, and how they were assessing the risks posed by COVID-19 in comparison to those posed by domestic violence. Since proceedings in family, child welfare, criminal law, and to secure civil protection orders are the domains with which survivors of domestic violence most frequently engage, we have focused on judicial decisions rendered during this time period in these areas. Restricting our search to only those cases where there was an allegation or finding of domestic violence yielded a total of just sixty-seven decisions.

Given the timeframe of our search it is not surprising that most of the reported decisions involved allegations (or findings) of domestic violence that had occurred prior to the pandemic. Yet the ongoing risks of domestic violence and the heightened risks in the context of COVID-19 ought nonetheless to be relevant considerations in the context of cases involving, for example, judicial interim release, civil protection orders, and custody and access arrangements.

While the judicial decisions are important and revelatory in many respects, there are a great many questions that they leave unanswered and we have flagged many of these in later sections of the article, noting as well the data that needs to be gathered in order to answer them. For example, while there is some indication that requests for Emergency Protection Orders $(\mathrm{EPO}(\mathrm{s}))$ have gone up in Alberta post COVID-19 and that requests for family law restraining orders are lower than anticipated in Ontario, good data on the numbers of applications and orders is required. Similarly, while there are many indications that calls to police for assistance related to domestic violence have gone up in many parts of the country, to date little information is available about how policing, charging, and prosecutorial practices may have changed during the pandemic and how these may, in turn, filter the sorts of cases that ultimately make their way into reported decisions over the months to come.

Nonetheless, our assessment of the sixty-seven decisions issued in this period does provide several insights. Importantly, court directives across the country have prioritized "urgent" cases, often explicitly including access to various forms of protective orders for victims of domestic violence and in some jurisdictions, modifications in legal aid eligibility and services have been implemented to facilitate access to legal advice and representation. However, overall the cases reveal very little awareness of the heightened risks for survivors as a result of COVID-19. Though disappointing, in some respects this is not surprising. The tendency of decision makers in all areas of the law to focus on incident-based physical violence rather than patterns of coercive control has been documented 
and critiqued for some time; that the novel tactics of coercive control now being deployed should escape notice is entirely consistent with this tendency. Particularly in the family law context, the strict interpretation of "urgency," the urging by courts for parties to work things out on their own, and the significant procedural complexity accompanying virtual motions may well be operating to limit survivors' access to the custody and access arrangements and protection orders that might shield them and their children from on-going domestic violence.

The cases also reveal significant differences in the interpretation of the risks of COVID-19 and of these risks relative to those of domestic violence. In the criminal law context, while there are clearly different approaches taken by various judges charged to determine judicial interim release, the harms of COVID-19 are often described as dire, unprecedented, and potentially deadly. Similarly, in the child welfare context, the risks of COVID-19 are seen to provide ample justification to end access by biological parents to a child in foster care. By contrast, in the family law decisions, descriptions of the risks of COVID-19 are far more muted. Although superficial note is made of public health directives limiting contact, the risks of having children regularly moving back-and-forth between households never register as being terribly significant and they pale in comparison to the importance courts attach to maintaining contact with both parents. And while in many of the criminal cases there is an explicit balancing of the risks of COVID-19 and the risks of violence to the complainant, in the family law cases the risks of domestic violence are minimized alongside the minimization of the risks of COVID-19. While the risks of congregate living in jails certainly differ from those attendant on moving between two households, there is a significant qualitative difference in how COVID-19 and its risks are described and weighed in decision making. Moreover, the differences between the family and child welfare decisions cannot be explained by these variants in living conditions. Rather these different approaches, we suggest, are better explained by Marianne Hester's theory of three planets, each with its own set of norms, particular understanding of and assumptions about domestic violence, and legislative frameworks. The norms and assumptions associated with one planet — criminal law, for example-are not merely distinct from, but often in tension or direct conflict with, those associated with the other planets-family law and child welfare law. These tensions and contradictions result in the lack of a coherent approach and serve to undermine the safety of women and children. ${ }^{8}$

8. Marianne Hester, "The Three Planet Model: Towards an Understanding of Contradictions in Approaches to Women and Children's Safety in Contexts of Domestic Violence" (2011) 41 Brit J Soc Work 837. The three-planet concept is discussed more fully in the conclusion. 
In Part I we explore in some detail the emerging data on COVID-19 and domestic violence. We briefly consider the data not only from Canada, but elsewhere around the globe, to make clear why violence against women has been characterized as a pandemic. Here we consider not only the rise in rates of domestic violence, but in its severity and complexity. We then consider the multiple pathways that connect the COVID-19 pandemic and the violence against women pandemic. Before turning to the consideration of how courts have responded, we briefly canvass the difficulties women are experiencing in accessing counselling, health, and shelter services. While these are important in their own right, they also have implications for women's participation in court proceedings, including whether they are able to provide the evidence to establish domestic violence. The limited availability of shelter beds, of rehabilitation and child welfare services, and the closing of supervised access centres also leave their imprint on judicial decision making. The final issue we address in this part is the availability of legal advice and representation and the specific measures introduced in some provinces and territories to facilitate survivors' access to justice during the pandemic.

In Part II we first describe the methodology used to generate our case sample and then turn to a detailed discussion of the reported decisions in family law, child welfare law, criminal law, and the laws pertaining to civil protection and restraining orders. Here we draw out the themes noted briefly above, highlighting not only those emergent in each area of law, but how themes compare across these areas.

In Part III, the conclusion, we provide an overall assessment of how well Canada has done in prioritizing women's safety in its response to COVID-19. While some positive steps have been taken, we suggest that COVID-19 has laid bare many of the gaps in knowledge about domestic violence and in the supports and resources necessary to make women and children safe that long pre-dated COVID-19's arrival. We offer a number of suggestions of measures necessary to ensure access to justice not only during COVID-19 and other disasters, but to address the ongoing pandemic of violence against women. 


\section{COVID-19 AND THE SHADOW PANDEMIC OF DOMESTIC VIOLENCE}

\section{A. THE EMERGING DATA ON COVID-19 AND DOMESTIC VIOLENCE}

The UN Special Rapporteur on violence against women issued a statement on 27 March 2020, warning that restrictive measures to fight COVID-19 would intensify the risk of domestic violence: ${ }^{9}$

It is very likely that rates of widespread domestic violence will increase, as already suggested by initial police and hotline reports. For too many women and children, home can be a place of fear and abuse. That situation worsens considerably in cases of isolation such as the lockdowns imposed during the COVID-19 pandemic. ... To make matters worse, restrictions of movement, financial constraints and generalized uncertainty embolden perpetrators and provide them with additional power and control.

Reports of increases in domestic violence have continued to proliferate. As of the time of writing, many of the reports derive from single data sources, such as shelters, hotlines, and police services in various jurisdictions around the globe. And as noted by others, systematically gathering national data is extremely important, not only during the pandemic but well beyond. ${ }^{10}$ As with other disasters and emergencies, the impact of COVID-19 on the rates, complexity, and severity of domestic violence will be felt well beyond the declared "ending" of the pandemic. ${ }^{11}$

Commentators have described the circumstances of "isolation paired with psychological and economic stressors ... and increases in negative coping

9. UNHR, "States must combat domestic violence," supra note 4.

10. United Nations Women, "Violence Against Women and Girls: Data Collection during COVID-19” (17 April 2020), online (pdf): <www.unwomen.org/-/media/headquarters/ attachments/sections/library/publications/2020/vawg-data-collection-during-covid-19compressed.pdf?la=en\&vs=2339> [perma.cc/F4XU-RYAK].

11. Andrew M Campbell, "An Increasing Risk of Family Violence During the Covid-19 Pandemic: Strengthening Community Collaborations to Save Lives" (2020) 2 Forensic Sci Intl 100090; Caroline Bradbury-Jones \& Louise Isham, "The Pandemic Paradox: The Consequences of COVID-19 on Domestic Violence” (2020) 29 J Clinical Nursing 2047. 
mechanisms"12 during COVID-19 as a "ticking time bomb,"13 a "powder keg," 14 and a "perfect storm." ${ }^{15}$ Reports from around the globe to date indicate increases in the number of calls for assistance related to domestic violence generally ranging from $10-50$ per cent, with a 25-30 per cent increase being common in many countries. ${ }^{16}$ An American study comparing domestic violence calls to police in fifteen large US cities found an increase of 10.2 per cent over the same time period last year. Significantly, increases were reported in city blocks without a recent history of domestic violence, suggesting new households are placing calls for assistance. ${ }^{17}$ In an Australian survey administered over a one-month period in April to May 2020 to 166 frontline service providers, 59 per cent of respondents reported an increase in the frequency of domestic violence, and 42 per cent reported that the pandemic had resulted in first-time family violence reported by women. ${ }^{18}$

12. Kim Usher et al, "Family Violence and COVID-19: Increased Vulnerability and Reduced Options for Support" (2020) 29 Intl J Mental Health Nursing 549 at 550; See also N van Gelder et al, "COVID-19: Reducing the Risk of Infection Might Increase the Risk of Intimate Partner Violence" (2020) 21 EClinical Medicine 100348.

13. Caroline Bettinger-Lopez, "A Double Pandemic: Domestic Violence in the Age of COVID-19" (13 May 2020), online: Council on Foreign Relations <www.cfr.org/in-brief/ double-pandemic-domestic-violence-age-covid-19> [perma.cc/S9W8-AK7R].

14. Raisa Patel, "Minister says COVID-19 is Empowering Domestic Violence Abusers as Rates Rise in Parts of Canada" (27 April 2020), online: $C B C<\mathrm{cbc}$.ca/news/politics/ domestic-violence-rates-rising-due-to-covid19-1.5545851> [perma.cc/Z2ZE-KXKY].

15. UN, "Supporting victims during COVID-19," supra note 4, citing UN Women Executive Director Phumzile Mlambo-Ngcuka; See Usher, supra note 12.

16. For a review of rates reported in various countries, see "COVID-19 and Ending Violence Against Women and Girls" (2020) at 2-3, online (pdf): UN Women <https://www.unwomen. org/-/media/headquarters/attachments/sections/library/publications/2020/issue-brief-covid19-and-ending-violence-against-women-and-girls-en.pdf?la=en\&vs=5006> [perma. cc/7V9K-6XE4]; Brad Boserup, Mark McKenney \& Adel Elkbuli, "Alarming Trends in US Domestic Violence During the COVID-19 Pandemic," (2020) Am J Emergency Medicine. In the United Kingdom, Respect, a domestic violence charity, reported a 97 per cent increase in calls, a 185 per cent increase in emails, and a 581 per cent increase in website visits. See UN, "Supporting victims during COVID-19," supra note 4.

17. Emily Leslie \& Riley Wilson, "Sheltering in Place and Domestic Violence: Evidence from Calls for Service during COVID-19” (19 May 2020), online: <papers.ssrn.com/sol3/papers. cfm?abstract_id=3600646> [perma.cc/27XZ-6NWS].

18. Naomi Pfitzner, Kate Fitz-Gibbon \& Jacqui True, "Responding to the 'Shadow Pandemic': Practitioner Views on the Nature and Responses to Violence Against Women in Victoria, Australia during the COVID-19 Restrictions" (8 June 2020), online (pdf): Monash University $<$ bridges.monash.edu/articles/Responding_to_the_shadow_pandemic_practitioner_views_ on_the_nature_of_and_responses_to_violence_against_women_in_Victoria_Australia_ during_the_COVID-19_restrictions/12433517> [perma.cc/5PAM-QMRX]. 
In the Canadian context Maryam Monsef, the Federal Minister for Women and Gender Equality, reported on 27 April 2020 that consultations with frontline organizations revealed a $20-30$ per cent increase in rates of domestic violence in some regions in Canada, and in the case of one shelter in the Greater Toronto Region, a 400 per cent increase in calls for assistance. ${ }^{19}$ Vancouver's Battered Women's Support Services reported in early April 2020 a 300 per cent increase in calls over the prior three week period. ${ }^{20}$ Various police forces have also reported an increase in domestic violence calls ${ }^{21}$ and a Statistics Canada survey of 4,600 Canadians conducted between 29 March 2020 and 3 April 2020 found that 10 per cent of women reported being very or extremely concerned about the possibility of violence in the home, as did 6 per cent of men. ${ }^{22}$

While limited data exists to date on rates of violence during COVID-19 against women who experience multiple and intersecting forms of oppression, a recent report from Human Rights Watch documents the heightened risks of gender-based violence for older women, women with disabilities (particularly those who are institutionalized, where shelter-in-place orders can make detection of abuse extremely difficult), foreign domestic workers (who are often locked in households and have no or limited access to public safety nets), and women

19. Patel, supra note 14. See also Wendy Gillis, "Forced to stay home with their abusers, Canadian victims of domestic violence must "choose between two pandemics"

(20 April 2020), online: The Toronto Star <www.thestar.com/news/canada/2020/04/20/ forced-to-stay-home-with-their-abusers-canadian-victims-of-domestic-violence-mustchoose-between-two-pandemics.html> [perma.cc/NML8-VGP3]; Deepa Mattoo \& Alina Butt, "Re: United Nations Special Rapporteur on Violence Against Women—Call for Submissions: COVID-19 and the Increase of Domestic Violence Against Women" (30 June 2020), online (pdf): Barbara Schlifer Commemorative Clinic <www.schliferclinic.com/ wp-content/uploads/2020/07/UN-Submission-re-COVID-19-and-VAW-June-30-2020-1. pdf> [perma.cc/S2YZ-5KD5].

20. Rumina Daya \& Jon Azpiri, "Calls to Vancouver domestic-violence crisis line spike 300\% amid COVID-19 pandemic" (7 April 2020), online: Global News <www.globalnews.ca/ news/6789403/domestic-violence-coronavirus/> [perma.cc/XF2M-DMY2].

21. For example, police in Saskatoon reported 484 domestic violence calls in March 2020 by comparison to 359 in 2019; See Brady Lang, "Saskatoon police sees drop in dispatched calls in March, domestic violence calls up" (14 April 2020), online: 650 CKOM <www. ckom.com/2020/04/14/saskatoon-police-sees-drop-in-dispatched-calls-in-march-domesticviolence-calls-up/> [perma.cc/ZYX7-9T86].

22. Statistics Canada, Canadian Perspectives Survey Series 1: Impacts of COVID-19, Catalogue No 11-001-X (The Daily, 8 April 2020) [Statistics Canada, "Canadian Perspectives"]. 
without or with limited access to technology. ${ }^{23}$ In Canada, the Native Women's Association has raised concern about the spike in the number of Indigenous women facing violence, noting that of 250 Indigenous women surveyed, 1 in 5 reported experiencing physical or psychological violence since the pandemic began. ${ }^{24}$ Concerns have also been sounded about the particular and exacerbated vulnerabilities during COVID-19 for non-status migrant women. ${ }^{25}$ Although these are early findings, they are entirely consistent with historical data documenting the differential burden of pandemics, with marginalized communities bearing the brunt. ${ }^{26}$

23. Human Rights Watch, "Submission to the UN special rapporteur on violence against women, its causes and consequences regarding COVID-19 and the increase in domestic violence against women" (3 July 2020), online: Human Rights Watch News <www.hrw.org/ news/2020/07/03/submission-un-special-rapporteur-violence-against-women-its-causes-andconsequences\#_ftn1> [perma.cc/CC9U-E3FQ]. These concerns have also been expressed by Special Rapporteur Simonovic. See United Nations Human Rights "States must combat domestic violence in the context of COVID-19 lockdowns 00 UN Rights Expert" (27 March 2020), online: UN Human Rights News and Events <www.ohchr.org/EN/NewsEvents/Pages/ DisplayNews.aspx?NewsID=25749\&LangID=E> [perma.cc/L9WW-JTPW].

24. Teresa Wright, "Violence against Indigenous women during COVID-19 sparks calls for MMIWG plan" (10 May 2020), online: $C B C<$ www.cbc.ca/news/canada/manitoba/ violence-against-indigenous-women-action-plan-covid-19-mmiwg-1.5563528> [perma.cc/QSW4-W4ND].

25. Salina Abji, Margarita Pintin-Perez \& Rupaleem Bhuyan, "In Canada, non-status women are being left behind" (27 May 2020), online: Open Democracy <www.opendemocracy. net/en/pandemic-border/canada-non-status-women-are-being-left-behind/> [perma.cc/CKR2-ZNAF].

26. See e.g. Ruqaiijah Yearby \& Seema Mohapatra, "Law, Structural Racism, and the COVID-19 Pandemic" (2020) Saint Louis University School of Law Legal Studies Research Paper Series, No 2020-08, online: <academic.oup.com/jlb/article/doi/10.1093/jlb/lsaa036/5849058> [perma.cc/7VJR-3ZZ3]; Janet E Mosher, “Accessing Justice Amid Contagion” (2014) 51 Osgoode Hall LJ 919; Lawrence O Gostin \& Alexandra Phelan, "The Ebola Epidemic: A Global Health Emergency” (2014) 312 J Am Medical A 1095; Harvey Kayman \& Angeal Ablorh-Odjidja, "Revisiting Public Health Preparedness: Incorporating Social Justice Principles in Pandemic Preparedness Panning for Influenza" (2006) 12 J Pub Health Mgmt \& Prac 373; Jonathan Purtle, "Racial and Ethnic Disparities in Post-Disaster Mental Health: Examining the Evidence Through a Lens of Social Justice" (2012) 19 Wash \& Lee J CR \& Soc Just 31; Kathleen Tierney, "Social Inequality, Hazards, and Disasters" in Roland J Daniels et al, eds, On Risk and Disaster: Lessons from Hurricane Katrina (University of Pennsylvania Press, 2006) 109. The strength of the association between income status and death led many commentators to estimate post-SARS that of the sixty-two million deaths projected for the next major influenza pandemic, an astounding 96 per cent would be in lowand middle-income areas, whether domestically or globally. In Canada, 25.65 per cent of those hospitalized during the H1N1 outbreak in 2008 were of Aboriginal ancestry, yet they comprised only 4 per cent of the population. During the influenza pandemic of 1918-19 the 
But not all agencies, shelters, and police services are reporting increases, and even where increases are reported there is very good reason to think that the currently reported numbers do not represent the full scope of the problem. ${ }^{27}$ Most women do not report to police; they are far more likely to turn to informal mechanisms of support, including family and friends. ${ }^{28}$ Moreover, in the current context where many women are (or have been until recently) isolated in their homes with their abusers and where their phone and internet use is closely monitored, the ability to reach out for support and advice can be extraordinarily limited and attempts to do so, dangerous. Additionally, given the rapid pace of change, the closure of all but essential services, and the plea by public health officials to remain at home, it was no doubt difficult for women to discern what services were still operating. ${ }^{29}$

In addition to the impact on the rates of domestic violence, increases in severity and complexity have been reported. In the Australian survey noted above, 50 per cent of respondents reported an increase in the severity of family violence and 55 per cent reported an increase in complexity. Disturbingly, from some jurisdictions, including Canada, there have been reports of an increase

death for Aboriginal peoples was five times the rate of non-Aboriginal persons; for further discussion, see Mosher, supra note 26.

27. Laurie Pawlitza, "No surge in domestic violence cases during COVID-19 lockdownthat doesn't mean it's not happening" (2 June 2020), online: Financial Post <business. financialpost.com/legal-post/no-surge-in-domestic-violence-cases-during-covid-19lockdown-but-its-happening> [perma.cc/FHE3-2Q4C]; National Domestic Violence Hotline, "A Snapshot of Domestic Violence During COVID-19" (5 June 2020), online: <www.thehotline.org/2020/06/05/a-snapshot-of-domestic-violence-during-covid-19/> [perma.cc/M5UH-MAJS].

28. According to Statistics Canada's 2014 General Social Survey on victimization, 19 per cent of victims of spousal violence contacted the police themselves (a further 10 per cent reported the police learned of the violence in some other way); See Statistics Canada, Family Violence in Canada: A Statistical Profile, 2014, Catalogue No 85-002-X (Juristat, 21 January 2012) at 10.

29. See e.g. CBC News, "YWCA director concerned after family violence shelter use drops to zero amid pandemic," (07 May 2020), online: CBC News North <www.cbc.ca/news/canada/ north/domestic-violence-shelters-nwt-covid-19-1.5556398> [perma.cc/6F7Q-D94N]. 
in the number of cases of strangulation and of intimate femicide. ${ }^{30}$ The UN cautions that violence against women is taking on a new complexity: Exposure to COVID-19 is being used as a threat and "[a]busers are exploiting the inability of women to call for help or escape and women risk being thrown out on the street with nowhere to go." ${ }^{31}$ A variety of other COVID-19 specific tactics of power and control have also been reported: the use of misinformation about the virus to frighten and control victims; the withholding of necessary safety items, such as hand sanitizer and disinfectants; preventing access to medical advice and services by invoking exposure to the virus; the withholding of economic support; forbidding handwashing; denying access to communication methods; and preventing women from leaving home to work citing infection concerns, or accusing women of attempting to infect them if women have left the home for work. ${ }^{32}$ Frontline service providers in the Australian survey reported that

30. Pfitzner, Fitz-Gibbon \& True, supra note 18. On average one woman is killed by her intimate partner every six days in Canada but in the first month of the pandemic at least nine women and girls were killed in likely domestic homicides; See Molly Hayes, "At least nine women and girls killed in domestic homicides in Canada during pandemic" (last updated 13 May 2020), online: The Globe and Mail: Crime and Justice <www.theglobeandmail.com/canada/ article-at-least-nine-women-and-girls-killed-in-domestic-homicides-in-canada/> [perma.ccl VNH8-FE3J]; Jamie Grierson, "Domestic abuse killings 'more than double' amid Covid-19 lockdown" (15 April 2020), online: The Guardian: Domestic Violence <www.theguardian.com/ society/2020/apr/15/domestic-abuse-killings-more-than-double-amid-covid-19-lockdown> [perma.cc/TBE3-C8PG].

31. Michelle Milford Morse \& Grace Anderson, "The Shadow Pandemic: How the COVID-19 Crisis is Exacerbating Gender Inequality" (14 April 2020), online: United Nations Foundation $<$ unfoundation.org/blog/post/shadow-pandemic-how-covid19-crisis-exacerbating-genderinequality/> [perma.cc/MC9E-D8QV].

32. Pfitzner, Fitz-Gibbon \& True, supra note 18; Victoria Gibson, "Domestic violence organizations laud new funding, but call for more supports as COVID-19 escalates risk" (16 April 2020), online: iPolitics <ipolitics.ca/2020/04/16/domestic-violenceorganizations-laud-new-funding-but-call-for-more-supports-as-covid-19-escalates-risk/> [perma.cc/JRE4-MJBC]; Campbell, supra note 11; The Learning Network, University of Western Ontario, "Intimate Partner Violence in a Pandemic: COVID-19-Related Controlling Behaviours," online (pdf): The Learning Network at the Centre for Research \& Education on Violence Against Women \& Children <www.vawlearningnetwork.ca/our-work/ infographics/LN-COVID-19-Related-Controlling-Behaviours-PDF-2.pdf> [perma.cc/ B86N-XU68]; Wendy L Patrick, "Domestic Abuse and Quarantine: When the Threat is Inside" (19 March 2020) online: Psychology Today <www.psychologytoday.com/ca/blog/ why-bad-looks-good/202003/domestic-abuse-during-quarantine-when-the-threat-is-inside> [perma.cc/S6YY-AZX2]. 
perpetrators are using children and COVID-19 as a pretext to gain access to women, particularly where shared care arrangements are in place. ${ }^{33}$

The correlation between COVID-19 and domestic violence is bidirectional: Not only does COVID-19 increase the risk of domestic violence, but survivors are at higher risk of infection, co-morbidities, and long-term consequences of the pandemic. ${ }^{34}$ Moreover, domestic violence harms women's abilities to recover from disasters. ${ }^{35}$

\section{B. PATHWAYS LINKING COVID-19 AND DOMESTIC VIOLENCE}

While increases in domestic violence are no doubt an unintended consequence of the public health and other measures to contain and respond to COVID-19, they are not unanticipated. A significant volume of research documents the increases in gender-based violence, including domestic violence, during and long after pandemics and disasters of various sorts. ${ }^{36}$ An even larger volume of research has revealed the strong correlation between common outcomes produced by such events-isolation, stress, unemployment, increased alcohol consumption, and deterioration in mental well-being — and domestic violence. ${ }^{37}$

A common tactic of coercive controllers is to isolate their victims, cutting them off socially (from friends and family), physically and geographically (restricting their movements, in some instances confining victims to the home), and functionally (supports may exist but are unreliable or aligned with the perpetrator). ${ }^{38}$ Emma Williamson's metaphor of a cage aptly captures the

33. Pfitzner, Fitz-Gibbon \& True, supra note 18. Note too, that pandemics are also associated with the exacerbation of xenophobia-related violence, harassment, and other forms of violence in public spaces. UN Women has observed during COVID-19 an increase in online violence against women, as well as increased sexual exploitation and abuse. See "UN Women raises awareness," supra note 2. ("Some groups of women, including human rights defenders, women in politics, journalists, bloggers, women belonging to ethnic minorities, indigenous women, lesbian, bisexual and transgender women, and women with disabilities are particularly targeted by ICT-facilitated violence" (ibid)).

34. Amber Peterman et al, "Pandemics and Violence Against Women and Children" (1 April 2020) at 6, online (pdf): Center for Global Development <www.cgdev.org/sites/default/files/ pandemics-and-vawg-april2.pdf> [perma.cc/Q4TM-U92Z].

35. Katie Lauve-Moon \& Regardt J Ferreira, "An Exploratory Investigation: Post-Disaster Predictors of Intimate Partner Violence" (2017) 45 Clinical Soc Work J 124 at 125.

36. Ibid; See also Campbell, supra note 11; Peterman et al, supra note 34; Emily W Harville et al, "Experience of Hurricane Katrina and Reported Intimate Partner Violence" (2011) $26 \mathrm{~J}$ Interpersonal Violence 833.

37. An extensive review of this literature is provided by Peterman et al. See Peterman et al, supra note 34 .

38. $\mathrm{N}$ van Gelder et al, supra note 12 . 
experience of many women living with a coercive controller. ${ }^{39}$ Locked inside the home-physically and psychologically-the abuser's portrayal of reality may be the only portrayal to which a victim has access..$^{40}$ Quarantine, physical distancing, and shelter-in-place public health orders map exquisitely onto an abuser's desire to control his intimate partner, adding yet more authority to his edicts and in some jurisdictions, backed by the coercive power of the state that can be applied in the event an order is breached. As many advocates have pointed out, to be locked inside the home with the perpetrator can be profoundly unsafe for women and for children, yet public health messages consistently portray the home as the place of safety. ${ }^{41}$

There is ample evidence that economic insecurity and poverty within the family produce stress, which in turn is correlated with domestic violence. ${ }^{42}$ And there is no question that COVID-19 has generated significant economic insecurity, unemployment, and poverty. But as with virtually all burdens associated with pandemics, this burden is not borne equally. Women have been more impacted by job loss than men (the monthly decline in employment for women was

39. "Living in the World of the Domestic Violence Perpetrator: Negotiating the Unreality of Coercive Control" (2010) 16 Violence Against Women 1412.

40. Ibid. See also Stephanie Sweetnam, "Where Do You Think Domestic Violence Hurts Most?" (2013) 19 Violence Against Women 133.

41. Usher et al, supra note 12. For the literature on the risks to children of coercive control, see Callaghan, supra note 3; Schafran, supra note 3; See also S Artz et al, "A Comprehensive Review of the Literature on the Impact of Exposure to Intimate Partner Violence for Children and Youth" (2014) 5 Intl J Child, Youth \& Family Studies 49; L Bancroft, J Silverman \& D Ritchie, The Batterer as Parent: Addressing the Impact of Domestic Violence on Families (Sage, 2012). Bancroft, Silverman, and Ritchie emphasize how children are harmed by the active undermining of their relationship with their primary parent (mother) by an abusive parent both before and after separation. This ultimately impedes children's recovery from the damaging effects of exposure to abuse as they are better able to deal with toxic stress when they have a strong supportive relationship with their primary parent. See Center on Developing the Child, Harvard University, "Toxic Stress," online: Key Concepts $<$ developingchild.harvard.edu/science/key-concepts/toxic-stress/> [perma.cc/ZPS6-SAUZ].

42. Peterman et al, supra note 34; Campbell, supra note 11; The Learning Network, University of Western Ontario "COVID-19 \& Gender-Based Violence in Canada: Key Issues and Recommendations" (2020), online (pdf): The Learning Network at the Centre for Research \& Education on Violence Against Women \& Children <www.vawlearningnetwork.ca/docs/ COVID-gbv-canada-recommendations.pdf> [perma.cc/67P2-J5Z9] [Learning Network, "COVID-19 \& Gender-Based Violence"]. 
more than twice that of men in March), ${ }^{43}$ creating greater financial dependency. Financial dependency, in turn, can make leaving an abusive relationship difficult: In the face of potential poverty and homelessness, staying in the relationship may seem to be a better choice. Not all women are equally impacted by the COVID-19 pandemic and the associated economic crisis; it is women from marginalized communities whose work is always precarious and under-valued who are most harshly impacted.

Pandemics, together with associated quarantine, stay-at-home orders or public health messaging not to leave the home unless essential, and physical distancing measures contribute to problematic coping behaviours (such as drug and alcohol consumption), anxiety, and mental health disorders, including serious psychological consequences such as depression and post-traumatic stress disorder ${ }^{44}$ Alcohol, drug abuse, and mental health disorders are also correlated with domestic violence. ${ }^{45}$

These various factors - stress, poor mental health, isolation-are not only correlated with domestic violence, but are among the risk factors for lethal violence. Ontario's Domestic Violence Death Review Committee has, over a fifteen-year period, reviewed 329 cases involving the deaths of intimate partners in order to isolate the common risk factors. These factors include various characteristics and behaviours on the part of the perpetrator that may be heightened or triggered by COVID-19: depression, obsessive behaviour, excessive alcohol and drug use,

43. See Jolson Lim, "Youth, women, precarious workers bear brunt of COVID-19 job losses, Statistics Canada finds" (9 April 2020), online: iPolitics <ipolitics.ca/2020/04/09/ youth-women-precarious-workers-bear-brunt-of-covid-19-job-losses-statistics-canada-finds/> [perma.cc/8QZ7-YGWH]; Statistics Canada, Labour Force Survey, March 2020, Catalogue No 11-001-X (The Daily, 9 April 2020) at 7. The Statistics Canada findings are based on the Labour Force Survey conducted during the week of March 15 to 21.

44. N van Gelder et al, supra note 12 .

45. Peterman et al, supra note 34; Learning Network, "COVID-19 \& Gender-Based Violence," supra note 42. In a survey undertaken by Statistics Canada in April 2020, 13.6 per cent of respondents reported an increase in alcohol consumption, although this data is not broken down by gender; Statistics Canada, "Canadian Perspectives," supra note 22. Across the country the sale of alcohol was deemed an essential service and stores remained open. 
unemployment, prior attempts to isolate the victim, and control of most or all of the victim's daily activities. ${ }^{46}$

\section{ACCESSING SERVICES AND SUPPORTS}

While the risk factors for domestic violence have gone up, the ability to access services and supports has become more difficult. Many service providers have quickly moved a number of counselling, safety planning, mental health, and other services to remote delivery, but for survivors who are effectively locked in their homes with abusers, and where their phone and internet use is likely to be closely monitored, accessing these services may not be possible. Moreover, the gender and class digital divide means that many survivors will not have access to the technologies that are needed to facilitate access to services. ${ }^{47}$ This is a particular concern for women from marginalized communities. Service providers in the United Kingdom, for example, have reported that: ${ }^{48}$

[T] he Covid-19 crisis has exacerbated a lack of access to services for migrant and Black, Asian, and minority ethnic (BAME) women, particularly as resources go digital. Representatives of organizations serving these communities say that persistent inequality, including access to the internet, leads to additional difficulties in providing services remotely. As one Black feminist service provider in Newcastle, England, explained, "Twenty-five percent of the women we support don't even have a phone, let alone a smart phone. [Digital services] assume a baseline of access."

The civil society organizations that provide critical supports to survivors of gender-based violence faced challenges in meeting women's service needs well

46. Ontario, Office of the Chief Coroner, Domestic Violence Death Review Committee 2018 Annual Report, (December 2019) (Chair, Deidre Bainbridge), at 15, online (pdf): <www.mcscs.jus.gov.on.ca/sites/default/files/content $/ \mathrm{mcscs} / \mathrm{docs} /$ DVDRC\%202018\%20Annual\%20Report.pdf> [perma.cc/Q95R-QNQ9]. Another factor is access to or possession of firearms; US data shows an increase in purchases of guns and ammunition during COVID-19. On the connection between coercive control and lethal violence against children, see Lori Chambers, Deb Zweep \& Nadia Verelli, "Paternal Filicide and Coercive Control: Reviewing the Evidence in Cotton v Berry" (2018) 51 UBC L Rev 671; on preventing child homicides in the context of domestic violence, see Katreena Scott et al, "Child Homicides in the Context of Domestic Violence: When the Plight of Children is Overlooked” in Peter Jaffe, Katreena Scott \& Anna-Lee Straatman, eds, Preventing Domestic Homicides: Lessons Learned from Tragedies (Academic Press, 2020) c8; Katherine Reif \& Peter Jaffe, "Remembering the Forgotten Victims: Child-Related Themes in Domestic Violence Fatality Reviews" (2019) 98 Child Abuse \& Neglect 104223.

47. Human Rights Watch, "Submission to the UN," supra note 23.

48. Ibid. 
before the pandemic. COVID-19 has generated an increased need for services and supports from under-funded organizations that are also having to rapidly change their service delivery models.

There is evidence in some of the cases reviewed in Part II, below, that survivors' diminished access to counselling, health, and other services is, as one might predict, impairing their ability to seek justice in that they are unable to access the sources of evidence often insisted upon to "verify" the abuse, establish their credibility, or meet other evidentiary thresholds. ${ }^{49}$ The constraints produced by COVID-19 in accessing sources of verification compound the pre-existing challenges that have prevented legal systems from responding effectively to the needs of survivors.

The ability to access safe shelter-both emergency and long-term-is fundamental to the human right of women and children to live free of violence. Intimate partner violence is a significant cause of women's homelessness, and the threat of homelessness, a reason many women remain in, or return to, abusive relationships. ${ }^{50}$ Seeking safe housing elsewhere has been made difficult by various public health orders (including shelter-at-home and quarantine orders and travel prohibitions). These orders limit the potential for women to move in temporarily with family or friends, and also impact their access to violence against women shelters. Even prior to the COVID-19 pandemic the need for shelter services outstripped beds available; Statistics Canada's annual snapshot survey undertaken 18 April 2018 revealed that on that day, 669 women, 236 children, and 6 men were turned away, most often because the facility was full. Of the women who left a facility on that day, 21 per cent were returning to a residence where the perpetrator continued to live. ${ }^{51}$ And while shelters are a vital resource for women experiencing violence, it is also important to note that shelters are more accessible to some women than others. In some parts of the country there are no shelters, and the option of flying out of one's community is highly unlikely during COVID-19; many shelters are physically inaccessible to

49. See Peterman et al, supra note 34 (providing an example of how delays in medical testing during Ebola resulted in legal cases being thrown out (at 16)).

50. For documentation of this invisibility in detail, see Kaitlin Schwan et al, "The State of Women's Housing Need \& Homelessness in Canada" (Canadian Observatory on Homelessness, June, 2020), online (pdf): <womenshomelessness.ca/wp-content/uploads/ State-of-Womens-Homelessness-Literature-Review.pdf> [perma.cc/5NYT-THL9].

51. Statistics Canada, Canadian Residential Facilities for Victims of Abuse, 2017/2018, by Greg Moreau, Catalogue No 82-002-X, (Juristat, 17 April 2019), online (pdf): <www150.statcan. gc.ca/n1/pub/85-002-x/2019001/article/00007-eng.htm> [perma.cc/7BVL-9XEW]. 
women with disabilities, and culturally inaccessible for many Indigenous women and immigrant women. ${ }^{52}$

Since the pandemic was declared there have been significant injections of funding for shelters, some specifically targeted to shelters for domestic violence survivors, sexual assault centres, and other frontline service providers who work with survivors. The federal government announced in early April 2020 up to thirty million dollars to address the immediate needs of shelters and sexual assault centres and a further ten million dollars to support the existing network of shelters on First Nations reserves and in the Yukon. ${ }^{53}$ Various provincial and territorial governments have also provided additional financial supports, although often in a block of funds that include other forms of emergency shelter and residential facilities. ${ }^{54}$

52. Wright, supra note 24 .

53. Women and Gender Equality Canada, News Release, "Government of Canada supports over 500 women's shelters and sexual assault centres during the COVID-19 pandemic" (16 May 2020), online: Government of Canada <www.canada.ca/en/status-women/news/2020/05/ government-of-canada-supports-over-500-womens-shelters-and-sexual-assault-centresduring-the-covid-19-pandemic.html> [perma.cc/54CL-P6S4].

54. For example, Ontario committed up to forty million dollars to support organizations that provide residential services for child and youth, people with developmental disabilities, and emergency shelters for women and families fleeing domestic violence. See, Ontario Ministry of Children, Community and Social Services, News Release, "Ontario Protecting Vulnerable Ontarians During COVID-19 Outbreak” (4 April 2020), online: Ontario Newsroom <news.ontario.ca/mcys/en/2020/04/ontario-protecting-vulnerable-ontariansduring-covid-19-outbreak.html> [perma.cc/K9CZ-6YEE]; Saskatchewan committed \$171,000 for emergency shelters. See, Government of Saskatchewan, "Province Announces Social Services Pandemic Response" (31 March 2020), online: News and Media <www. saskatchewan.ca/government/news-and-media/2020/march/31/social-services-pandemicresponse> [perma.cc/WEW3-85A3]; Nova Scotia, \$535,000 for transition houses and other organizations that support vulnerable women and their children. See Nicole Munro, "Organizations seek funding to house domestic violence victims in HRM hotels during pandemic" (16 April 2020), online: The Chronicle Herald <www.thechronicleherald.ca/ news/local/organizations-seek-funding-to-house-domestic-violence-victims-in-hrm-hotelsduring-pandemic-438414/> [perma.cc/6V3K-YCMJ]; Alberta, sixty million dollars toward adult homeless shelters, women's emergency shelters and Family and Community Support services program. See CBC News, “'This is a serious moment in our history': Alberta Premier Jason Kenney declares public health emergency" (17 March 2020), online: CBC News Edmonton <www.cbc.ca/news/canada/edmonton/this-is-a-serious-moment-in-ourhistory-alberta-premier-jason-kenney-declares-public-health-emergency-1.5500562> [perma. cc/53GV-GM3H]; Québec, \$2.5 million towards the goal of meeting the increased needs of assistance and accommodation organizations for women victims of conjugal violence and abused women living with multiple social problems. See Québec, Secrétariat à la condition féminine, "COVID-19: 2,5 millions de dollars supplémentaires pour soutenir les victimes 
Importantly, in most provinces and territories shelters have been declared an essential service. ${ }^{55}$ Estimates place the increased calls to shelters from survivors at 20-40 per cent. ${ }^{56}$ Shelters have had to profoundly change how they work: fewer staff on site, lower volume of intakes to maintain physical distancing, stepped-up cleaning, isolation for those infected, screening on intake, moving other services online. So, while additional funding is desperately needed, it is hard to imagine that it comes anywhere close to meeting the needs of women for shelter where they are safe from domestic violence and safe from COVID-19.

An additional complexity arises where women and children share common spaces within a shelter. Some shelters have adopted policies to protect residents and staff that preclude leaving and returning. This is especially challenging in cases where the father has access rights; a child who leaves the shelter may be precluded from returning. As far as we have been able to discern, Québec is the only province to address this explicitly, passing a directive on 10 April 2020, suspending existing custody or access rights in an agreement or order where the parent with custody was residing in a shelter for victims that had imposed isolation restrictions on residents, although contact was to be maintained through other means and subject to a court lifting the suspension (and there are cases in our sample where courts were persuaded to do so). ${ }^{57}$

de violence" (27 March 2020), online: <www.scf.gouv.qc.ca/nouvelles/communiques/ salle-de-presse/detail/news/covid-19-2-5-millions-de-dollars-supplementaires-pour-soutenirles-victimes-de-violence/> [perma.cc/EL5Y-KXJ6].

55. We were unable to find information indicating whether shelters or shelter workers had been declared essential for Nunavut, Northwest Territories, and Prince Edward Island.

56. Wendy Gillis, "Forced to stay home with their abusers, Canadian victims of domestic violence must 'choose between two pandemics" (20 April 2020), online: Toronto Star $<$ www.thestar.com/news/canada/2020/04/20/forced-to-stay-home-with-their-abuserscanadian-victims-of-domestic-violence-must-choose-between-two-pandemics.html> [perma. cc/84AX-5P53]; The Shift, "Conversation on COVID-19 and Women's Homelessness" (6 May 2020), online (video): Youtube <www.youtube.com/watch?v=5oYSjSPFark> [https:// perma.cc/S8QW-285W].

57. Québec, Ministerial Directive 2020-020 of the Minister of Health and Social Services (10 April 2020), online (pdf): <cdn-contenu.quebec.ca/cdn-contenu/adm/min/ sante-services-sociaux/publications-adm/lois-reglements/AM_2020-020-anglais. pdf?1586613277>. Courts have lifted the suspension where the evidence shows that the particular living arrangements of the mother and child do not require them to share common areas with other shelter residents. See $A B v B A, 2020$ QCCS 1324; $M W v N M, 2020$ QCCS 1213 [MWv NM]; AL v NB, 2020 QCCS 1192 [AL v NB]; Lafond v Blouin, 2020 ONSC 2396 [Lafond]. In $M W v N M$, a mother who resided in a shelter for immigrant women obtained provisional sole custody of the nine-month-old child on this basis, with internet access to the father. In $A L v N B$ however, the suspension was not lifted because in-person visits with the father would have had the unreasonable consequence of requiring 
Another critical support to facilitate women's access to justice is legal advice and representation. Legal Aid plans vary significantly across the country on many dimensions, including the qualifying income thresholds, the areas of law covered, and the range of service delivery models (legal information, duty counsel, full representation by counsel, et cetera). In New Brunswick (Minister of Health and Community Services) $v G(J),{ }^{58}$ the Supreme Court of Canada held that section 7 of the Charter is engaged where the state seeks to remove children from parental custody and that the principles of fundamental justice require, in some instances, state-funded legal representation of the parent. This means that parents are more likely to have access to counsel for child protection matters than in private family law proceedings. In the latter context, for those who meet the low-income thresholds, representation by counsel in family law matters involving issues of custody and access is, or may be, available under provincial and territorial legal aid plans, and some plans explicitly prioritize cases where there is an allegation of domestic violence. Funding for representation to secure or review EPOs is also available in several provinces. In the pre-COVID context, significant numbers of litigants were unrepresented in private family law matters, and the challenges of self-representation in this arena have been well-documented. ${ }^{59}$ In the context of matters involving domestic violence, mustering the evidence to prove the abuse, dealing with the interplay of family, criminal, and child welfare law, and the realities of the inequalities in power make self-representation a formidable challenge. As such, legal aid pre-COVID, like so much of the infrastructure of supports needed to ensure the safety of women and children, was inadequately resourced.

In the context of COVID-19 and the increased risks to women, several provinces appear to have made no changes to legal aid eligibility criteria or to services, other than altering how applications for legal aid are to be made. ${ }^{60}$

the four-year-old child to wear a mask for fourteen days. In the Ontario case of Lafond, the father alleged abuse by the mother and wanted to deny her access because of her residence in a shelter; however, she was resident in a separate hotel suite and found able to minimize her child's exposure to other children and abide by the relevant protocols. In all of these cases, the focus was on COVID-19 risks and the allegations of domestic violence and its potential risks were not addressed.

58. [1999] 3 SCR 46.

59. See e.g. Action Committee on Access to Justice, Meaningful Change for Family Justice: Beyond Wise Words_Final Report of the Family Justice Working Group (April 2013); Law Commission of Ontario, Increasing Access to Family Justice Through Comprehensive Entry Points and Inclusivity (LCO, 2013); Julie MacFarlane, The National Self-Represented Litigants Project: Identifying and Meeting the Needs of Self-Represented Litigants (May 2013).

60. Our findings here are based on a review of the websites of legal aid providers in each province and territory. 
The most significant exception is Legal Aid Ontario, which quickly announced that during the COVID-19 crisis, all legal and financial eligibility criteria for domestic violence survivors would be waived, and that this would remain in effect until further notice. ${ }^{61}$ Legal Aid Ontario's website includes a specific acknowledgement that "staying home is not always safe and that during the COVID19 crisis, it is important to help survivors protect their personal safety and continue providing critical family law services." ${ }^{\prime 2}$

Legal Aid Alberta introduced measures specifically designed to facilitate victims' access to EPOs, with duty counsel working remoting to provide legal advice, document preparation, and representation over the phone. ${ }^{63} \mathrm{~A}$ new, temporary service was also introduced to provide after-hours access (from 3:00 $\mathrm{pm}-10: 00 \mathrm{pm}$ ) for duty counsel to support victims of family violence at hearings before a Justice of the Peace. Legal Aid Alberta's website expressly notes that this process was developed "in response to increased demands for Emergency Protection Orders," adding that "[h]aving this extra assistance available to victims of domestic violence will make the process of obtaining an Emergency Protection Order much less stressful for the clients and improve access to justice during COVID-19." Victims of domestic violence in Alberta also have access to a free lawyer to assist with the Queen's Bench Review process that is necessary to determine if the EPO should be confirmed. ${ }^{64}$

In British Columbia, Legal Aid BC (Legal Services Society) moved family duty counsel and family advice lawyer services from in-person to phone-only. ${ }^{65}$ Its "Family Law-Legal Help for People of BC" website, like Ontario's, speaks directly to the concerns raised during COVID-19 if confined at home with an abusive partner, and provides self-help videos on how to obtain a protection

61. Legal Aid Ontario, "Domestic Violence services during COVID-19" (last modified 5 August 2020), online: <www.legalaid.on.ca/services/domestic-abuse/> [https:// perma.cc/TNY2-9V29].

62. Ibid.

63. Legal Aid Alberta, "Legal Aid Supports for Victims of Family Violence During COVID-19, online (pdf): <www.legalaid.ab.ca/SiteAssets/Pages/default/Support\%20for\%20Victims \%20of\%20Family\%20Violence\%20During\%20COVID-19.pdf> [https://perma.cc/ QU46-JMUP].

64. For a further discussion of EPOs see Part III, below.

65. Legal Aid BC, "Legal aid service updates," online: Legal Aid BC News <lss.bc.ca/ communications/news/legal-aid-service-updates $>$. 
order during COVID-19, along with information about how to access services from shelters and crisis lines. ${ }^{66}$

Yukon introduced a free independent legal advice (not representation) program for victims of domestic violence and sexual assault, ${ }^{67}$ while Nova Scotia introduced service alterations in the family law realm, although not specifically designed to address domestic violence. In addition to new measures to address child and spousal support variations during COVID-19, it is providing free online chats on family law issues twice per week during a two-hour window and expanded telephone family summary advice (which is available to anyone, including those not financially eligible for other services). ${ }^{68}$

The heightened risk of domestic violence, the expansion of tactics of control, and the increased challenges women face in accessing services each and together threaten the safety of women and children in significant ways and have important implications for women's access to justice.

\section{COURT-BASED DECISION MAKING}

In this Part we turn our attention to law and as noted earlier, particularly those areas of law that routinely and profoundly impact the safety of survivors of domestic violence: family law, child welfare law, criminal law, and the laws that provide for various forms of protection orders. ${ }^{69}$ Here we review the general directives from courts prioritizing what matters would proceed and consider how judges have interpreted and applied these directives and more generally, decided cases involving domestic violence during the first six weeks of the COVID-19

66. Jackie Hong, "Yukon government launches free legal advice program for victims of sexual violence" (10 June 2020), online: Yukon News <www.yukon-news.com/news/ yukon-government-launches-free-legal-advice-line-for-victims-of-sexual-violence/> [perma.cc/42WS-CM36].

67. Family Law, "COVID-19 updates_abuse \& family violence," online: Abuse \& Family Violence < familylaw.lss.bc.ca/abuse-family-violence/covid-19-updates-abuse-familyviolence> [perma.cc/768X-2GQ7]; Legal Aid Nova Scotia, "Expansion of Family Law Summary Advice and Online Chats" (26 March 2020), online: News <www.nslegalaid.ca/ expansion-of-family-law-summary-advice-and-online-chats/> [perma.cc/3TCG-ME9V].

68. Legal Aid Nova Scotia, "Support Variations During COVID-19” (20 May 2020), online: News <www.nslegalaid.ca/support-variations-during-covid-19-new-ways-to-help/> [perma.cc/8LZL-U255].

69. We have separately analyzed cases that involve surveillance and technology-facilitated abuse, which cross-cut different areas of law. See Jennifer Koshan, Janet Mosher \& Wanda Wiegers, "COVID-19, Domestic Violence, and Technology-Facilitated Abuse," online (blog): ABlawg, University of Calgary, Faculty of Law <www.ablawg.ca/2020/07/13/covid-19-domesticviolence-and-technology-facilitated-abuse/> [perma.cc/RDM6-WL74]. 
pandemic. We did not set out to conduct a quantitative analysis of relevant cases but rather were interested in knowing whether the decisions reflected an appreciation of the risks of both the COVID-19 pandemic and of the shadow pandemic, and more generally how survivors' access to justice was impacted.

\section{A. METHODOLOGY}

For this Part of the article, we searched court directives issued by provincial, territorial, and superior courts in all Canadian jurisdictions after the pandemic was declared in mid-March, 2020-a period when courts across the country were shut down and limited matters were permitted to proceed by way of teleconference or other electronic means. We also searched cases on CanLII using terms inclusive of domestic violence and the COVID-19 pandemic. ${ }^{70}$ The search led to sixty-seven relevant cases involving applications made and/or decided between 16 March 2020 and 1 June 2020 where there was an allegation or finding of intimate partner violence, even if it occurred before then. ${ }^{71}$ We counted cases as relevant where they dealt with domestic violence issues that were related to the pandemic in some way, but did not include cases where the courts simply mentioned COVID-19 as relevant to procedure or where COVID-19 did not play a role in the decision to hear the case or in the arguments or outcome. We also included cases where courts consider whether particular domestic violence related matters are "urgent" and eligible to be heard on the merits. Our intention was to review the cases to identify issues and approaches that were either helpful or problematic for alleged victims of domestic violence. As noted above, most of the cases in this timeframe involve domestic violence that allegedly occurred before the pandemic and this, together with the anticipated long-term impacts of COVID-19 on domestic violence survivors, indicate that case tracking for the period subsequent to 1 June 2020 will be important for analyzing whether and how the shadow cast by COVID-19 is seen and handled by the courts.

70. Terms included "family," "domestic," "interpersonal violence," "abuse," and "no contact," in combination with "COVID 19," "coronavirus," "pandemic," as well as "violence conjugale," "violence familiale" with "COVID," "pandemie." We supplemented our list with cases from the Luke's Place database that these search terms did not produce; See Luke's Place, "Recent COVID-19 cases," online: Archive for Case Law <lukesplace.ca/category/case-law-2/> [perma.cc/Z7JT-8SV4].

71. There were fifty-nine English and eight French decisions that we identified as relevant after reading a larger sample of cases decided between these dates. These cases were noted up, to July 7 , and relevant decisions in the same case are also included in our analysis, even if they were rendered after 1 June 2020 — though they are counted as one case. 
It is also important to note that there was a great disparity of results from different Canadian jurisdictions in the number of relevant written decisions that we found, with most cases coming from Ontario (50), followed by Québec (8), British Columbia (4), Nova Scotia and Newfoundland / Labrador (2 each), Alberta (1), and no reported cases from the rest of the provinces and territories. While this pattern aligns somewhat with the more populous regions of the country with higher overall numbers of COVID-19 infections, it does raise questions as to the complete absence or low number of cases in many other provinces and territories where the incidence of domestic violence is known to have increased. ${ }^{72}$

It may be that courts in some jurisdictions are less likely to produce written reasons for decisions during the COVID-19 pandemic. For example, in a webinar held in April 2020, the Chief Justice and Associate Chief Justice of the Alberta Court of Queen's Bench indicated that written reasons on "urgency" decisions were unlikely because the Court was in triage mode. ${ }^{73}$ In addition, as noted by Pamela Cross, the Legal Director of Luke's Place in Oshawa, Ontario, "those who have consulted with a lawyer are wary of the urgency threshold imposed by the courts, even though they need a restraining order or exclusive possession of the home." ${ }^{74}$ These are important issues from an access to justice perspective. Judicial decisions — even on questions of urgency—should be publicly available as they provide transparency, accountability, and guidance to counsel and clients as to what matters will be heard. Written decisions are also an important means of combatting perceptions about lack of access to the courts—or perhaps confirming them, especially in family law cases where the parties are being urged to "work it out" before using the courts' resources.

72. We are not in a position to compare these rates with what would otherwise be the typical case load at this time of year. However, we know from other case law research pre-pandemic that the rates of family cases involving intimate partner violence have been disproportionately high in Ontario compared to Saskatchewan and Alberta, even given the differences in population. This disparity suggests that further research is needed into the problems survivors ordinarily experience in different jurisdictions in accessing the courts.

73. See Jennifer Koshan, "Domestic Violence and Legal Responses to COVID-19 in Alberta" (10 April 2020), online (blog): ABlawg <ablawg.ca/2020/04/10/domestic-violence-andlegal-responses-to-covid-19-in-alberta> [perma.cc/9DE9-LM75]. For a rare family decision on urgency in Alberta, see SAS v LMS, 2020 ABQB 287. While this case did not involve domestic violence, Justice Robert Graesser noted that the parties should engage in "good faith attempts to communicate ... and good faith attempts to arrive at reasonable solutions" before coming to court during the pandemic, "barring a restraining order or Family Protection Order" (at paras 38-39).

74. Pawlitza, supra note 27. 
The low numbers of written decisions in some jurisdictions may further reflect the fact that many of the conditions surrounding the pandemic, including the difficulty in accessing services as discussed earlier, make it quite likely that even cases that would satisfy the courts' definitions of urgency are not being brought to the courts by survivors of violence. This is also cause for concern and among the questions for which data ought to be gathered.

\section{B. FAMILY LAW CASES}

Family law cases made up two-thirds of the cases in our case sample. Such claims may proceed under the Divorce $A c t^{75}$ or under provincial or territorial family legislation. Recent amendments to the Divorce Act that would add family violence as a factor relevant to parenting orders were expected to come into force 1 July 2020 but have now been delayed until 1 March 2021 because of the COVID-19 pandemic. ${ }^{76}$ Unlike the current Divorce Act, some provincial statutes such as Ontario's Children's Law Reform Act expressly mandate consideration of family violence in making parenting orders. ${ }^{77}$ However, most of the forty-three family law decisions did not identify whether the claim or order was made under the federal or a provincial statute. Although a few decisions dealt with financial matters such as spousal support and family property, the vast majority of family law decisions during the relevant period involved applications for parenting orders i.e., custody and access. The vast majority also involved allegations of domestic violence made by women against men, with only five cases alleging abuse by the mother or mutual violence.

In most of the family cases in our sample, two major issues were generally to be determined: whether an additional threshold requirement of urgency had been met for a hearing to proceed and if so, what the substantive outcome should be on its merits. In relation to both of these issues, the cases generally illustrate the continuing appeal of two trends that emerged in the 1970s and have been dominant in family law jurisprudence since the 1980s. One such trend has been referred to by Noel Semple as the "settlement mission," to capture the efforts by judges in the context of an under-resourced legal system to encourage or pressure

75. RSC 1985, c 3 (2nd Supp) [Divorce Act].

76. Bill C-78, An Act to amend the Divorce Act, the Family Orders and Agreements Enforcement Assistance Act and the Garnishment, Attachment and Pension Diversion Act and to make consequential amendments to another Act, 1st Sess, 42nd Parl, 2019, (assented to 21 June 2019) [Divorce Act]. For a critique of this delay, see Pamela Cross, "Justice Delayed," online (blog): <www.pamelacross.ca/justice-delayed/> [perma.cc/P8W7-JS7A].

77. RSO 1990, c C-12, s 24(4) [Children's Law Reform Act]. 
parties into resolving conflicts outside of trials. ${ }^{78}$ Concerns about the impact of the settlement mission in cases of domestic violence have been voiced repeatedly by feminist scholars and others who have drawn attention not only to the harms that may be experienced in individual cases given power differentials and safety risks, but also to the erosion of public norms through the privatization of justice. ${ }^{79}$ The other equally significant trend has been the importance courts have placed on "maximum contact" or on maintaining relationships between children and both of their parents. ${ }^{80}$ Here too, feminists have long expressed concern about the impact of this emphasis on contact in the context of domestic violence. ${ }^{81}$ The dominance of both of these normative positions reveals a common failure to fully understand domestic violence, the shape it takes post-separation, and the harms it imposes on women and children. As suggested in the Introduction, above, it is perhaps then not surprising that many of the family law decisions made in the course of the COVID-19 pandemic fail to reflect the increased risks to women and children described in Part I, above, and fail to consider the more subtle and complex dynamics of domestic violence. Indeed, the cases reveal much about the incredible stronghold these norms have on family law decision-making: courts have doubled down on the pressure to settle and have continued to promote on-going contact with both parents, notwithstanding the risk of domestic violence and the risks of COVID-19. The assessment of the risks surrounding COVID-19 in these family law decisions is particularly jarring when compared to the assessment made in several of the child welfare and criminal law cases.

78. "Mandatory Family Mediation and the Settlement Mission: A Feminist Critique" (2012) 24 CJWL 207.

79. Wanda Wiegers \& Michaela Keet, "Collaborative Family Law and Gender Inequalities: Balancing Risks and Opportunities" (2008) 46 Osgoode Hall LJ 73; Linda C Neilson, "At Cliffs Edge: Judicial Dispute Resolution in Domestic Violence Cases" (2014) 52 Fam Ct Rev 529; LC Neilson, Responding to Domestic Violence in Family Law, Civil Protection \& Child Protection Cases (Canadian Legal Information Institute, 2020) [Neilson, Responding to Domestic Violence]; Lesley Laing, "Secondary Victimization: Domestic Violence Survivors Navigating the Family Law System” (2017) 23 Violence Against Women 1314; Echo A Rivera, Chris M Sullivan \& April M Zeoli, "Secondary Victimization of Abused Mothers by Family Court Mediators” (2012) 7 Feminist Crim 234; David Greatbatch \& Robert Dingwall, "The Marginalization of Domestic Violence in Divorce Mediation" (1999) 13 Intl JL Pol'y \& Fam 174; Sara Cobb, "The Domestication of Violence in Mediation" (1997) 31 Law \& Soc'y Rev 397.

80. See Divorce Act, supra note 76, s 16(1).

81. See e.g. Susan B Boyd, Child Custody, Law, and Women's Work (Oxford University Press, 2003). For similar concerns that have been identified in other countries, see Rosemary Hunter, Adrienne Barnett \& Felicity Kaganas, "Introduction: Contact and Domestic Abuse" (2018) 40 J Soc Welfare \& Fam L 401. 


\section{URGENCY}

In Ontario, where most of the cases were decided, court directives for both the Ontario Court of Justice and the Superior Court of Justice generally limited family court matters as of 17 March 2020 to motions that were urgent. ${ }^{82}$ According to the Superior Court's Directive, urgent matters included "urgent relief relating to the safety of a child or parent" (e.g., restraining orders, exclusive possession orders), those related to "the well-being of a child" including "the wrongful removal or retention of a child," and "dire issues regarding the parties' financial circumstances" (e.g., non-depletion orders). ${ }^{83}$ This directive was amended over time and further notices to the profession that had been issued in different regions were consolidated in a province-wide directive effective 19 May $2020 .^{84}$ These directives are substantially similar to those issued in other jurisdictions, most of which have limited motions to urgent or emergency situations, including safety concerns arising from a risk of violence or immediate harm to a party or child. ${ }^{85}$

82. For a list of different directives of the Ontario Court of Justice over time, see Luke's Place, "Supporting women to access family law supports during COVID-19" (24 June 2020), online: Service Providers, Legal News \& Strategy <lukesplace.ca/supporting-women-to-accessfamily-law-supports-during-covid-19/\#OCJ> [perma.cc/8XRP-8WWS].

83. "Notice to the Profession, the Public and the Media Regarding Civil and Family Proceedings: Suspension of Superior Court of Justice Regular Operations" (15 March 2020), online: Superior Court of Justice <www.ontariocourts.ca/scj/covid-19-suspension-fam/> [perma. cc/258D-U3K9] [Notice to the Profession, 15 March 2020].

84. See Ontario Superior Court of Justice, "Consolidated Notice to the Profession, Litigants, Accused Persons, Public and the Media" (13 May 2020), online: Notices and OrdersCOVID-19 <www.ontariocourts.ca/scj/notices-and-orders-covid-19/consolidated-notice/> [perma.cc/L5L8-KR3X] [Ontario Superior Court of Justice, "Consolidated Notice to the Profession"]. Subsequently, different regions have issued different directives with some retaining urgency as a threshold requirement and others allowing for the hearing of more non-urgent matters while prioritizing urgent or pressing motions.

85. For directives related to most of the cases within our sample, see British Columbia Supreme Court, "Notice to the Profession, the Public and the Media Regarding Civil and Family Proceedings COVID-19: Suspension of Regular Court Operations" (30 March 2020), at 2, online: <s3.amazonaws.com/tld-documents.llnassets.com/0018000/18398/ notice $\% 20$ of $\% 20$ suspension $\% 20$ of $\% 20$ civil $\% 20$ and $\% 20$ family $\% 20$ proceedings $\% 20$ revised\%20march\%2030,\%202020.pdf> [perma.cc/RJC7-D2T6]; Court of Queen's Bench of Alberta, "Master Order \#3 Relating to Court's Response to the COVID 19 Virus" (21 April 2020), online (pdf): <www.albertacourts.ca/docs/default-source/qb/covid/ master-order-3---covid-19---final.pdf?sfvrsn=c4c68280_8> [perma.cc/LT39-CSZW]. Québec included safeguard applications and custody and support applications within the category of urgent applications. See Justice Québec, Press Release, "Measures to be implemented in courthouses in response to COVID-19" (12 March 2020), online: <www. justice.gouv.qc.ca/en/press-releases/measures-to-be-implemented-in-courthouses-in-response- 
The interpretation of these directives by courts in the context of cases involving domestic violence, along with the procedures in place to get a matter before the courts, reveal potentially significant obstacles for survivors in accessing justice during COVID-19. According to early cases, findings of urgency were to be made on a preliminary and temporary basis. Urgent rulings are without prejudice to either party on the substantive merits of the motion and do not displace other statutory requirements or court-based rules. ${ }^{86}$ In Thomas $v$ Wohleber, a leading case which involved allegations by the wife of surveillance and financial abuse by her husband, Justice Kurz pointed out that the urgency requirement must be scrupulously and rigorously enforced. ${ }^{87}$ Concerns must require "immediate" resolution; they must also be serious, "definite" rather than speculative, "material" rather than theoretical, and must be "clearly particularized in evidence." 88 The onus of proving urgency is typically on the party advancing the motion in relation to each claim for relief. ${ }^{89}$

The high threshold established in Thomas and the need to demonstrate immediate or imminent, ${ }^{90}$ or material, tangible ${ }^{91}$ or demonstrable harm, can capture discrete and serious instances of financial abuse, such as the coerced indebtedness in Thomas, ${ }^{92}$ and may also capture discrete incidents of physical violence that are serious and recent. However, a focus on recent instances of serious physical or financial coercion fails to take account of the assemblage of stratagems and behavioural patterns that can, over a longer period, work to maintain coercive control. As indicated in our earlier discussion, COVID-19 has both expanded the tactics available to perpetrators in maintaining power and control and intensified others, including those that continue post-separation.

to-covid-19/> [perma.cc/PF4W-RS5D]. Directives varied in different courts in most jurisdictions and have been modified over time.

86. Berube v Berube, 2020 ONSC 2221 [Berube]. Thomas $v$ Wobleber, 2020 ONSC 1965

[Thomas] (discussing the requirements under the Family Law Rules that would ordinarily be required before hearing a formal motion and waiving a case conference, mandatory information conference, or allowing an ex parte application (at paras 25-30)).

87. Thomas, supra note 86 .

88. Ibid at paras 31-33, 38-39.

89. Thibodeau $v$ Molder, 2020 ONSC 2745 [Thibodeau]. The list is not exhaustive, and the determination of urgency is discretionary. See Kostyrko v Kostyrko, 2020 ONSC $2190[$ Kostyrko].

90. See e.g. JWv CH, 2020 BCPC 535.

91. See e.g. $L M B v F J D, 2020$ ONCJ 239 [ $L M B]$. In $L M B$, the judge found there was no "tangible evidence" of anger or addiction issues in response to the mother's evidence that "he assaulted me all the time" (ibid at para 87).

92. Thomas, supra note 86 . 
Since many, if not most, of the parents in our case sample had separated before the pandemic, COVID-19 was more likely to be related to efforts in the post-separation context to consolidate control over the victim. Although many control tactics commonly known to occur post-separation were evident in the recitation of facts in the custody or access decisions, the connections to coercive control were rarely drawn. ${ }^{93}$ These tactics included attempts to discredit mothers as parents by accusing them of using drugs or having mental health issues, ${ }^{94}$ or to undermine their relationships with their children by encouraging or forcing the children to report mothers to child protection authorities or sign affidavits against them, ${ }^{95}$ or otherwise threatening to take the children away or isolating the children from them, ${ }^{96}$ as well as electronic surveillance, ${ }^{97}$ a failure to abide by previous orders ${ }^{98}$ and threats of numerous lawsuits. ${ }^{99}$ The high threshold for urgency thus can constitute a significant deterrent to the making and success of applications by victims of domestic violence during the pandemic.

In deciding on urgency, judges have also placed significant weight on pre-existing parenting arrangements in order to sustain contact between the child and both parents. In Ribeiro $v$ Wright, a case that did not involve domestic violence but has been frequently cited, ${ }^{100}$ Justice Pazaratz ruled that "in most situations, there is a presumption that existing parenting arrangements and schedules should continue, subject to modifications to ensure that COVID-19

93. See The Duluth Model, "Post Separation Power and Control Wheel" (2013), online (pdf): <www.theduluthmodel.org/wp-content/uploads/2017/03/Using-Children-Wheel.pdf> [perma.cc/ZG88-RXGT]; For more on legal bullying, see David Ward, "In Her Words: Recognizing and Preventing Abusive Litigation Against Domestic Violence Survivors" (2016) 14 J Soc Just 429; Heather Douglas, "Legal Systems Abuse and Coercive Control" (2018) 18 Crim \& Crim Justice 84.

94. See e.g. $A M D v K G, 2020 \mathrm{ABQB} 325[A M D]$. In $A M D$ the mother claimed abuse over a fifteen-year period.

95. See e.g. McCumber v Barnes, 2020 ONSC 2706 [McCumber].

96. AMD, supra note 94.

97. Pappas $v$ Volavka, 2020 ONSC 2856 [Pappas] (acknowledged by the father); Thomas, supra note 86 (alleged through Spyware); AMD, supra note 94 (describing where the father had installed "intrusive camera-monitoring" in the home before separation "to ensure, or help ensure, the mother was not neglecting the children" at para 28); See also Triestino v Triestino, 2020 ONSC 3311 [Triestino, Motion Order]; Triestino v Treistino, 2020 ONSC 3695 [Triestino, Motion Ruling]. For further discussion see in Part II(E), below.

98. Triestino, Motion Order, supra note 97 at para 4.

99. Pappas, supra note 97. Legal bullying was likely not as evident in our case sample since these were not final judgments based on a trial or on a lengthy history of proceedings.

100. Ribeiro $v$ Wright, 2020 ONSC 1829 [Ribeiro]. 
precautions are adhered to, including social distancing." 101 Where a parent had denied parenting time or withheld a child simply on account of COVID-19, they would then have to present specific evidence of conduct on the part of the other parent that was inconsistent with COVID protocols and that had placed the child or another household member at risk. Lacking such evidence, the child would continue to move between the two households. The existence of public health directives that favoured a "strict policy of social distancing and limiting community interactions as much as possible" were briefly acknowledged in Ribeiro, as were the existence and complications of blended families. ${ }^{102}$ But Justice Pazartz did not reference expert testimony on the health implications for the child and others arising from the regular or frequent exposure of a child to more than one household, nor examine the particular composition of the households in question. Instead, he stated: ${ }^{103}$

A blanket policy that children should never leave their primary residence-even to visit their other parent-is inconsistent with a comprehensive analysis of the best interests of the child. In troubling and disorienting times, children need the love, guidance and emotional support of both parents, now more than ever.

This assumption, that access should continue across two households, should be contrasted with the controversy that emerged when Premier Doug Ford had two of his daughters visit his home on Mother's Day. In this context, the Chief Medical Officer reiterated that contact should be limited to one's immediate household and that social distancing of two metres should apply to contact with all family members outside of one's household. ${ }^{104}$ The ready acceptance of regular visits across two households - an approach at odds with the advice of the Chief Medical Officer-attests to the deep imprint of familial ideology in custody cases.

101. Ibid at paras 11, 16-17. During the pandemic, the types of orders made by some courts have expanded to encompass standard directives such as physical distancing with persons outside of each party's household before, while, and after parenting time, avoidance of unnecessary out-of-home errands, frequent handwashing, wearing of masks, and compliance with other orders; See e.g. Masse v Phillips, 2020 ONSC 2906 [Masse]; Chahine v Martins, 2020 ONSC 1825 at para 36.

102. Ribeiro, supra note 100 at para 8.

103. Ibid at para 10.

104. Canadian Press, "Doug Ford appears to contradict official health advice by having daughters over" (12 May 2020), online: National Post News Canada <nationalpost.com/news/canada/ doug-ford-appears-to-contradict-official-health-advice-by-having-daughters-over-2> [perma. cc/F4DE-WVK7]; Sean Davidson, "Ontario premier sparks confusion over social gathering rules after weekend visit with daughters" (11 May 2020), online: CTV News Toronto $<$ toronto.ctvnews.ca/ontario-premier-sparks-confusion-over-social-gathering-rules-afterweekend-visit-with-daughters-1.4933644> [perma.cc/62KH-V77Z]. 
Susan B. Boyd, among others, has noted how family courts have restructured but also extended the nuclear family unit beyond divorce or separation based largely on a presumption that paternal contact is vital to a child's best interests. ${ }^{105}$ The notion of a post-divorce family unit also trades on an idealized view of a family home as a place of comfort and a refuge from external perils, a view of the home no doubt reinforced by public health messaging during COVID-19 but belied by the existence of domestic violence.

In our sample of cases involving allegations or findings of domestic violence, findings of urgency in applications for access or for the return of children were most often seen to relate to the general well-being of a child rather than to their or their mother's safety. Findings of urgency based on a child's well-being were particularly likely where a party had failed to provide access or failed to return a child contrary to an existing order or agreement. ${ }^{106}$ Where an existing order or agreement had not been breached and allegedly abusive fathers sought access, case outcomes on the question of urgency were mixed, with some cases finding no urgency because the health, safety, or well-being of the child was not threatened in the mother's care and the fathers had unreasonably delayed in advancing their claims. ${ }^{107}$ However, in most cases, judges found in favour of urgency in order to provide some access by fathers, including cases where fathers had been criminally charged and subject to no-contact orders vis-à-vis the mothers. ${ }^{108}$ In several decisions, judges did find or expressly suspect that fathers were using COVID-19 to gain a strategic advantage over the mother or impair her relationship with a child. In Flesias $v$ Flesias, for example, the father was found to be taking "tactical advantage of the pandemic" along with the mother's "lack of financial resources and her poor English language skills" in depriving her of access to the family

105. Boyd, supra note 81 at 134, 222.

106. See e.g. Kostyrko, supra note 89; Antora v Alam, 2020 ONCJ 220 [Antora]; Berube, supra note 86; Placha v Bennett, 2020 ONCJ 164 [Placha].

107. See e.g. Ramirz-Schrimshaw v Ingram, 2020 ONSC 2278; Reitzel v Reitzel, 2020 ONSC 1977; Sezin v Sheikh, 2020 ONCJ 187; Clemente v O'Brien, 2020 ONSC 3287 [Clemente] (neither urgent nor pressing in part because father had not engaged in settlement discussions or proposed options).

108. See e.g. GJ v B-LS, 2020 ONSC 3115 [GJ v B-LS]; LB-Mv MM, 2020 ONSC 1958 [LB-M]; Amir v Nazir, 2020 ONSC 2459; Pappas, supra note 97; Batchelor v Batchelor, 2020 ONSC 1921 [Batchelor]. 
home and to her son over a two-month period. ${ }^{109}$ Typically, however, the source of the urgency or concern has been framed not in terms of a history of domestic violence and related risk of harm to a child nor as a tactic used to maintain coercive control over a victim, but rather as the failure to support the ongoing relationship between the child and the other parent. ${ }^{110}$

In the leading cases during the timeframe of our sample, judges have also urged the parties to an even greater extent than pre-COVID-19 to work matters out themselves before initiating urgent court proceedings. ${ }^{111}$ Our case sample reveals that in many cases, judges simply assumed mothers who had alleged assault or domestic abuse should be conciliatory and compromising. For example, in Clemente $v$ O'Brien, where the father was charged with assault and sought access, the parties were expected, as a pre-condition to obtaining leave for an urgent case conference, to have "engaged in genuine, broadly optioned and diligent settlement discussions." ${ }^{112}$ In Antora $v$ Alam, notwithstanding that the father was facing an "outstanding criminal charge"113 and was subject to a no-contact order, Judge Clay insisted that through "proper communication of all available options" the parties could work out their own adjustments in scheduling access. ${ }^{114}$ Mediation services, available virtually, have been promoted on court and government websites although the latter have suggested that mediation "may not be a good idea" in cases of violence or abuse or where one party is afraid of the other spouse. ${ }^{115}$ An expectation of respectful communication may be productive where partners have ignored or failed to respond to concerns regarding care of the

109. 2020 ONSC 2368 at para 19 [Flesias]. See also GJv B-LS, supra note 108 at para 42; Edwardsv Robinson, 2020 ONSC 3658 at para 6 [Edwards]; McNeil v Christie, 2020 NSSC 145 at para 13 [McNeil]; McCumber, supra note 95 at para 14 . For cases that demonstrated a criticism of fathers who withheld children and sought to unilaterally change the status quo, see Placha, supra note 106; Kostyrko, supra note 89. But see Ivens v Ivens, 2020 ONSC 2194 (describing where the father had been "aggressive" towards the mother in the past but the mother was found to be using the "crisis as an excuse to usurp parental responsibilities" at para 126).

110. See TP $v$ CS, 2020 ONCJ 210 at para 64 [TP $v$ CS]. See also GJv B-LS, supra note 108. In $T P v C S$, the problem is also identified as exposure to parental conflict, and in $G J v B-L S$ the disruption of attachment to a primary parent is also of concern.

111. See e.g. Ribeiro, supra note 100, at paras 22-28, Pazaratz J.

112. Clemente, supra note 107 at para 33.

113. Antora, supra note 106 at para 5. See also Jordan v Steel, 2020 ONSC 2834.

114. Antora, supra note 106 at para 26.

115. Ontario, Ministry of the Attorney General, Family Mediation Services, online: Family Justice <www.attorneygeneral.jus.gov.on.ca/english/family/mediation.php $>$ [perma.cc/ RL2Z-LN5Q]. See also $L B-M$, supra note 108 (encouraging mediation). 
children but an expectation of cooperative problem solving may also be wholly unrealistic, if not dangerous in cases involving allegations of domestic violence.

Along with the need to establish urgency, court directives have imposed additional and complex procedural requirements on family litigants that make accessing justice more difficult, particularly if they are self-representing. ${ }^{116}$ In Ontario, urgency is or was to be determined in a separate preliminary motion; copies of all relevant orders and endorsements and all relevant facts and options were to be included with materials filed for each hearing as judges did not have access to physical files or scanned documents, ${ }^{117}$ and page limits along with time-limited hearings were also imposed in some regional notices. These requirements have generally presupposed access to a telephone and internet service for email communications with court officials and electronic filing of court documents, ${ }^{118}$ and in increasing the complexity of the process, the requirements have no doubt increased the cost of advancing a claim for represented litigants, and the difficulties experienced by unrepresented litigants. Added procedural complexity itself increases the burden on survivors who may have been traumatized by their experience, especially if subject to long term abuse.

The onerous urgency threshold established in the case law, the burden placed on parties to sort things out themselves, the inattention to the shadow pandemic, and the procedural complexity of urgency motions may explain why, according to counsel to the Chief Justice of the Superior Court of Ontario, fewer motions involving domestic violence were brought in the first three weeks of June than had been anticipated. ${ }^{119}$ While 45 per cent of urgent cases were family and/or child protection matters, and notwithstanding the waiver for victims of domestic violence of all legal and financial eligibility requirements for legal aid in Ontario, "only a handful of those urgent cases dealt with the fallout from domestic violence." 120

116. In our sample of forty-three family cases, thirteen litigants were unrepresented, including eight alleged perpetrators and three alleged victims of intimate partner violence.

117. See e.g. Antora, supra note 106 at para 24.

118. See Ontario Superior Court of Justice, "Consolidated Notice to the Profession, Litigants, Accused Persons, Public and the Media Re: Expanded Operations of Ontario Superior Court of Justice, effective 19 May 2020" (13 May 2020), online: Notices and Orders—COVID-19 $<$ www.ontariocourts.ca/scj/notices-and-orders-covid-19/consolidated-notice/\#1_Urgent_ Civil_and_Family_Proceedings> [perma.cc/3Q77-NX2M]. Hours in which courts were open for filing have also varied between regions.

119. Pawlitza, supra note 27. We note that this reference deals with a time period just outside of our case sample.

120. Ibid. 


\section{THE MERITS OF APPLICATIONS}

Judges are to consider only the best interests of a child in deciding applications for custody or access. In applying that test in the context of temporary or interim applications, they have stressed the importance of maintaining the status quo unless there is a compelling reason to change settled parenting arrangements. ${ }^{121}$ The status quo generally means parenting arrangements that existed before the separation of the parties, or those in place post-separation by order or agreement or for a substantial period of time with the acquiescence of both parties. As indicated above, courts have rejected attempts by one party to use COVID-19 to change the status quo and thereby gain a tactical advantage. ${ }^{122}$

Intimate partner violence can provide a compelling reason to alter the status quo since the adverse effects of such violence on children have been widely acknowledged, even where the violence is not directly witnessed, heard, or physically experienced by a child. ${ }^{123}$ But proving domestic violence is difficult where the violence is denied or criminal charges have not yet been prosecuted and likely more so during the COVID-19 pandemic when access to various sources of evidence that might provide verification is extremely limited. In some of the cases in our sample, a failure by fathers to respond to domestic violence allegations resulted in interim orders favouring mothers. ${ }^{124}$ In cases where the allegation was disputed, some judges made an effort to scrutinize inconsistent affidavits and identify which version of events was more credible. ${ }^{125}$ Others, however, simply assumed that each party has their "own version of events, [and] whose version is closer to the truth will have to be determined at a later date." 126 In Amirzada $v$ Alemy, for example, the mother had provided credible evidence of a physical assault by choking given criminal charges, hospital care, photos of this and prior assaults, along with texts that suggested the father's "controlling

121. See e.g. Berube, supra note 86; Ribeiro, supra note 100 at para 11; AMD, supra note 94.

122. See the text accompanying note 109 .

123. See the text accompanying notes $3,41,46$.

124. See e.g. Thibert $v$ Thibert, 2020 ONSC 2972 [Thibert]. In Thibert, the father denied the abuse but refused to explain what happened pending the criminal trial, leaving nothing to counter the mother's allegations; Flesias, supra note 109 (noting that such "choices have consequences” at para 30); Thibodeau, supra note 89; Soares v Kilgour, 2020 ONSC 2938 [Soares]. In Soares, the father did not attend the virtual hearing but no adverse inference was drawn against him given the limited options available to a court (i.e., involving the locking of the virtual hearing) if a self-represented litigant is late for the hearing (ibid at para 7).

125. See e.g. Flesias, supra note 109; Kostyrko, supra note 89; Soares, supra note 124 (casting doubt on the mother's allegations in this case).

126. Amiri v Nazer, 2020 ONSC 2459 at para 29 [Amiri]. 
manner." ${ }^{127}$ She alleged that the father had assaulted her while pregnant and in the child's presence but Justice Akbarali stated that "there is no allegation that the child has been harmed by the father." ${ }^{28}$ While a temporary joint custody order was set aside in light of the abuse allegations, Justice Akbarali refused to give the mother temporary sole custody since the allegations had not yet been "properly tested" and awarded the father three days per week of unsupervised access. ${ }^{129}$

It is understandably difficult to determine custody or to prohibit or limit access where the parties have diametrically opposed versions of events that have often occurred in private. This difficulty may be eased by more detailed scrutiny of affidavits and uncontested facts, the production of affidavits by third parties, expedited custody assessments, trial dates or viva voce hearings, and periodic reviews of interim orders. However, all such measures are much more difficult to undertake during a pandemic. Unless judges are willing to scrutinize the available evidence closely and, as Susan B. Boyd and Ruben Lindy suggest, draw inferences based on circumstantial evidence, they may, in awarding unsupervised access or almost equal parenting time, end up privileging the fathers' denial and erring on the side of furthering contact rather than exercising caution. ${ }^{130}$ This outcome may not only expose children and families to increased COVID-19 related risks in the short term but also expose children to coercive control or abuse on a long-term basis, as many such claims may not go to trial at all. In this sense, the status quo presumption and a pro-contact legal culture systematically prejudice claimants who have experienced domestic violence, exposing their children to a risk of continuing abuse. This is not an inevitable outcome as other cases (albeit pre-COVID-19) demonstrate that judges can err on the side of caution in

127. 2020 ONSC 1979 at para 31 [Amirzada].

128. Ibid. See also $A M D$, supra note 94 . In $A M D$ the mother was found to complain of the father's treatment of her, not the children, ignoring the harmful impact of abuse of a mother on children (ibid at para 34).

129. Amirzada, supra note 127 at para 36 . The mother's request to relocate with the child to Vancouver for extended family support during the pandemic was also refused.

130. "Violence Against Women and the B.C. Family Law Act: Early Jurisprudence" (2016) 35 CFLQ 101 at 115. For examples of such outcomes in our case sample, see Amirzada, supra note 127; Pappas, supra note 97; Amiri, supra note 126; Soares, supra note 124; Silva $v$ Silva, 2020 ONSC 3073 [Silva]. In Silva, access was to be supervised by the father's mother or brother. Note that in our sample, allegations of abuse by mothers of fathers, while uncommon, also appear to be discounted or ignored. 
interim matters where credible evidence suggests significant risk, without making an affirmative finding of abuse. ${ }^{131}$

In assessing the risk of harm to children in our case sample, judges, as well as children's aid societies, also tended to focus on recent discrete incidents of physical violence and ignore or discount the impact of coercive or controlling behaviour, including COVID-related control. The Children's Aid Society had not identified any "imminent safety concerns" in Amirzada, ${ }^{132}$ and had closed their file in Batchelor v Batchelor while acknowledging that the three-year-old child had been exposed to and emotionally affected by the father's physical and emotional abuse of the mother. ${ }^{133}$ Generally, very little detail was provided in judgments beyond bare allegations of controlling behaviour or emotional and psychological abuse. Notably, however, relief appeared far more likely when the court could frame coercive control tactics as alienation and as a failure to support the mother's or survivor's relationship with the children. ${ }^{134}$ In Flesias, the mother had alleged serious financial coercion and physical abuse by the father who had encouraged one of their children to file an affidavit denying such violence. ${ }^{135}$ Based on the concern that the father was actively discouraging a relationship between the mother and the children, she was awarded primary residence and exclusive possession of the family home, but the father obtained unsupervised access two to three days per week in spite of "serious concerns" about his behaviour. ${ }^{136}$ In Edwards $v$ Robinson, the mother, who claimed to be a victim of domestic violence over a twenty-year time span, had been denied contact with the two

131. See e.g. Malone v Allar, 2014 BCSC 1621 at para 64, SA Griffin J. See also RDMv XMM, 2017 BCSC 1674; LCT $v$ RK, 2015 BCSC 303. But see LCT $v$ RK, 2015 BCSC 2378, affd 2017 BCCA 64 on the parenting issue, where the trial judge found that the mother had exaggerated claims of sexual and domestic abuse by the father.

132. Amirzada, supra note 127 at para 31; Pappas, supra note 97 (expressing no concerns from the Society).

133. Batchelor, supra note 108.

134. See e.g. McCumber, supra note 95. For discussion of concerns regarding claims of alienation in the context of domestic violence, see e.g. Linda Neilson, Parental Alienation Empirical Analysis: Child Best Interests or Parental Rights?, (Muriel McQueen Fergusson Centre for Family Violence Research and Vancouver: The FREDA Centre for Research on Violence Against Women and Children, 2018); Elizabeth Sheehy \& Susan B Boyd, "Penalizing Women's Fear: Intimate Partner Violence and Parental Alienation in Canadian Child Custody Cases" (2020) 42 J Soc Welfare \& Fam L 80; Suzanne Zaccour, "Parental Alienation in Québec Custody Litigation” (2018) 59 C de D 1073; Madelyn S Milchman, Robert Geffner \& Joan S Meier, "Ideology and Rhetoric Replace Science and Reason in Some Parental Alienation Literature and Advocacy: A Critique” (2020) 58 Fam Ct Rev 340.

135. Flesias, supra note 109.

136. Ibid at para 44. 
youngest children by the father since the onset of the pandemic. ${ }^{137}$ Justice Jarvis found that the father was likely the partner responsible for the mother's physical injuries as referenced in hospital records, that he had failed to explain his entry into a peace bond in 2017, that his complaint to police three months after the mother had allegedly uttered threats was "prima facie, suspicious and suggestive of a tactical purpose," 138 that he had inappropriately involved the eldest child in the dispute, and that his allegation that the mother had substance abuse issues was contradicted by a recent hair follicle test. Overall, the father appeared "to be taking advantage of the current situation" not by relying on COVID-19 as the reason for curtailing access but it seemed by taking advantage of the impediments to "timely access to the court" during the COVID-19 pandemic. ${ }^{139}$ All of this conduct is suggestive of ongoing coercive control but unfortunately neither the court nor the mother's counsel identified this pattern of conduct as having or likely to have negative consequences for the children. Justice Jarvis in fact praised the mother for not criticizing the father and concluded that there was no reason to prefer either parent as a custodial or primary parent until a "more robust evidentiary record" was available. ${ }^{140}$ As requested by her counsel, shared parenting was ordered.

Concerns regarding the insistence by some judges on more robust or "properly tested" evidence before taking the risks of domestic violence, including coercive control, meaningfully into account are amplified in the context of COVID-19 both because of the known increase in risks and because the pandemic has made it more difficult to amass evidence in support of one's claim. These difficulties exist in addition to the challenge of ensuring that all relevant facts have been set out in affidavits and of collecting and having them sworn in times of physical distancing. In Masse v Phillip, the father alleged that the mother suffered from mental health issues that the mother acknowledged but attributed largely to his long-term abuse of her. ${ }^{141}$ Before increasing her access to the children, however, Justice Mitrow noted that she needed credible third party information regarding her mental health and that this would be difficult to obtain given the pandemic. ${ }^{142}$ In Amirzada, the court refused to order a custody and access assessment and noted that a report from the Ontario Children's Lawyer with respect to a young

137. Edwards, supra note 109.

138. Ibid at para 7.

139. Ibid at para 6 .

140. Ibid at para 8.

141. Masse, supra note 101.

142. Ibid at para 24. 
child could not be undertaken because of the need to physically distance. ${ }^{143}$ Few decisions were able to reference Voices of the Children reports or obtain input from children apart from instances where children had been encouraged, most often by fathers, to complain about the other parent. ${ }^{144}$

The inaccessibility of services has impeded not only the gathering of relevant evidence but has also limited the outcomes available in custody and access disputes. In "normal" times, supervised access may be available until trial if survivors can prove that restricted access is in the best interests of the child, generally by way of evidence that the risk of harm to the child outweighs the benefits of an open relationship with the other parent. ${ }^{145}$ Supervised access was ordered or left in place in only four cases in our sample, suggesting that this burden is an onerous one. ${ }^{146}$ While supervision is more likely to be ordered on a short-term basis, with the closure of supervision facilities, COVID-19 also raises more starkly questions as to who is a neutral, independent party who can supervise visits and whether supervision can be undertaken without increasing exposure of

143. Amirzada, supra note 127.

144. See e.g. Flesias, supra note 109; Edwards, supra note 109; McCumber, supra note 95. See also Thibert, supra note 124 (where the father had "allegedly enlisted one of the children to participate in an event designed to humiliate and degrade the mother" at para 5); Triestino, Motion Order, supra note 97; Triestino, Motion Ruling, supra note 97.

145. GJ v B-LS, supra note 108 at para 1, citing Young v Young, [1993] 4 SCR 3. Note too that in addition to being supervised, access may be made conditional upon participation in counselling by the abusive parent; however, none of the judgments in our case sample included such an order.

146. McNeil, supra note 109; Thibert, supra note 124; Silva, supra note 130; Triestino, Motion Order, supra note 97 (application for supervised access found to be urgent); Triestino, Motion Ruling, supra note 97 (supervision by the paternal grandparents subsequently found ineffective in preventing harassment of the mother by the father). See also Thibodeau, supra note 89 (where the father did not respond to the application and the children were ordered to be returned to the mother). See Michael Saini \& Rachel Birnbaum, "Raising The Bar: A Risk Assessment Checklist When Supervised Access Is Being Considered in Child Custody Disputes" (2015) 34 CFLQ 335. Saini and Birnbaum identify a host of problems with supervised access including little monitoring or follow up, little attention to children's experience and comfort levels, and a lack of accreditation for providers and access centres. See Fiona Kelly, "Enforcing a Parent-Child Relationship At All Cost? Supervised Access Orders in the Canadian Courts" (2011) 49 Osgoode Hall LJ 277 at 308 (finding in an analysis of decisions in Ontario and BC between 2006-2007 that even in cases of serious spousal or child abuse, judges "almost always" presumed that supervised access was in the best interests of children). 
the child or others to COVID-19. ${ }^{147}$ In the Amirzada decision discussed above, ${ }^{148}$ the father's unsupervised access was presumed safe in part because the father resided with four other adult family members who had a close relationship with the child. The mother's request to fly with the child to Vancouver to be with her extended family was denied, among other reasons, because of the risk arising from non-essential travel to the child and the public during the pandemic ${ }^{149}$ but physical distancing measures in relation to the father's extended family while the child was in his care were not addressed. Family members of the alleged abuser may often be identified for a supervisory role, ${ }^{150}$ but since the point of supervision is to watch out for problematic or harmful interactions with children, they are likely to be conflicted about reporting such problems and their participation may also increase the risks of surveillance of a victim by an abuser. ${ }^{151}$ Telephone or virtual access was ordered in relatively few cases in our sample ${ }^{152}$ and in any case, would likely be problematic with very young children. ${ }^{153}$ In only one of the cases reviewed was an application for access completely denied, and this was ordered on a temporary without prejudice basis where the father was in custody as a result of an assault charge. ${ }^{154}$

147. Triestino, Motion Ruling, supra note 97. In Triestino, Motion Ruling the mother applied to vary a temporary order giving the father in-person access to their two children, which was supervised in the paternal grandparents' home. The father repeatedly texted and emailed the mother while the children were with him on access visits during the pandemic, leading to charges of criminal harassment and breach of a restraining order. Justice Jarvis granted the mother's request to suspend in-person access "until supervised access facilities are permitted to re-open safely" and ordered access by the father via videocalls with the children in the interim, to be initiated by the mother (ibid at para 16).

148. Amirzada, supra note 127.

149. Ibid at para 31. But see EL $v N D, 2020$ QCCS 1451 (allowing the father to return to France with the children and acknowledging COVID-19 impacts only in relation to a potential delay in travel plans).

150. See e.g. Silva, supra note 130 (supervised by the father's brother or mother); Amirzada, supra note 127 (supervised access not needed because the father is living with his extended family); Triestino, Motion Ruling, supra note 97 (supervision by paternal grandparents found ineffective).

151. See Thibert, supra note 124. In Thibert, the father's application to have his parents or brother supervise access was denied for that reason. See also Rachel Birnbaum, "Virtual Parent-Child Contact Post-Separation: Hearing from Multiple Perspectives on the Risks and Rewards" (2020) 39 CFLQ 75.

152. See e.g. Triestino, Motion Ruling, supra note 97; Triestino, Motion Order, supra note 97.

153. See the text accompanying note 165 .

154. Harrington $v$ Dennison, 2020 ONSC 2114 [Harrington]. In Harrington, the father was charged with assault causing bodily harm to the mother by reason of strangulation while the mother was holding the sixteen-month-old infant as well as assault of her parents. 
In summary, COVID-19 has arguably rendered underlying systemic issues in parenting cases more visible. The "settlement mission" has intensified, with parties expected to sort things out themselves irrespective of power differentials and potentially at odds with public norms governing adjudication in family law matters. The public health messages of safety in the home align with the ideology of the family, contributing to both the invisibility and imprint of the shadow pandemic. Challenges in marshalling proof of domestic violence and in accessing services are endemic in the family law realm but have if anything increased during the timeframe of our case sample. Given a default assumption of contact, coercive control, in many respects the most damaging and corrosive form of abuse, is systematically minimized or ignored unless serious physical violence or threats have immediately preceded the application. All such concerns compromise access by women and children to safety and to equality in family violence cases. ${ }^{155}$

\section{CHILD PROTECTION}

Most provincial and territorial statutes expressly identify children to be in need of state protection or intervention where they have been exposed to family, interpersonal or domestic violence, or are likely to have been physically or emotionally harmed by it. ${ }^{156}$ During the pandemic, child protection matters have generally been more readily acknowledged than private family law cases to be "urgent" in court directives. For example, the Ontario Superior Court directive included in urgent child protection matters "all urgent or statutorily mandated events including the initial hearing after a child has been brought to a place of safety, and any other urgent motions or hearings." ${ }^{157}$ The Ontario Court of Justice included place of safety hearings, temporary care and custody hearings, restraining orders, status review hearings, and secure treatment orders. ${ }^{158}$

155. See The Honourable Donna Martinson \& Margaret Jackson, "Family Violence and Evolving Judicial Roles: Judges as Equality Guardians in Family Law Cases" (2017) 30 Can J Fam L 11 (criticizing the traditional adversarial system and lack of specialized judges in family violence cases).

156. See e.g. The Child, Youth and Family Services Act 2017, SO 2017, c 14 (CYFSA). See also Koshan, Mosher \& Wiegers, "The Costs of Justice," supra note at 7 at 16-17.

157. Notice to the Profession, 15 March 2020, supra note 83.

158. Note that under the authority of section 7.1(2) of the Emergency Management and Civil Protection Act, time limits for proceedings were suspended retroactively to 6 March 2020 and for the duration of the emergency. See Emergency Management and Civil Protection Act, RSO 1990, c E-9, s 7.1(2). 
However, COVID-19 has still had a serious impact on the handling of child protection matters and, as with many COVID-19 impacts, the parents and children most affected are economically disadvantaged. Although we know that a disproportionate number of families affected by the child protection system are also racialized, Indigenous, and/or living with physical or mental disabilities, ${ }^{159}$ in our sample of eight protection cases, none of the parties were identified as Indigenous and only one family appeared to be racialized. Several cases involved parents who were alleged to have substance abuse or mental health issues. Potential COVID-19 impacts included reduced oversight or reporting of child maltreatment as a result of social isolation as well as reduced opportunities for parents to visit their children while in state care or to meet conditions (such as counselling or attendance in parenting support programs) that could facilitate the return of their children. ${ }^{160}$ In British Columbia, presentation hearings that could identify whether children were in need of protection at the time of removal were delayed, with the result that the Ministry's decisions as to parental care could not in the interim be challenged. ${ }^{161}$

As well, some children in Ontario have been removed rather than placed with their parents under the supervision of a Society because of an inability to provide effective supervision during COVID-19. In CAS of Toronto v SS, ${ }^{162}$ Judge Zisman found that the mother needed counselling to understand domestic violence and its impact on children and to resolve her feelings for the father. Nonetheless, the court failed to expressly consider the mother's "contradictory behaviour patterns" (accusing the father of hitting the child but allowing him to care for the child and returning to live with him) in light of her experience of violence, along with the onerous demands of caring for a child with autism. In placing the child in the temporary care of the Society, judicial notice was taken of a number of significant constraints related to COVID-19: that many staff members were working remotely, that no home visits were being conducted, and that staff were responding in person only to emergency calls. ${ }^{163}$ Moreover, with schools and day care centres closed, there were no third parties to assist in monitoring the well-being of children under the supervision of the Society

159. For a discussion, see Judith Mosoff et al, "Intersecting Challenges: Mothers and Child Protection Law in BC" (2017) 50 UBC L Rev 435.

160. See $B C$ (CFCS) v KS, $2020 \mathrm{BCPC} 97$ at para 130 (discussing this in obiter).

161. Re BC (CFCS) v SMS 2020 BCPC 87, DL Dorey Prov CJ (suggesting that an application for parens patriae relief could be made to the Supreme Court of British Columbia).

162. 2020 ONCJ 170 [CAS of Toronto] (decided 2 April 2020).

163. Ibid at para 125 . 
and no community supports for caregivers. ${ }^{164}$ With minimal oversight and no other community supports, the mother, who Judge Zisman found had not been open and honest with the Society, could not be relied upon to provide proper care. Further, regarding the mother's access to the child while in state care, there were no drivers available to take children to and from visits and foster caregivers were concerned about visits in their homes due to the potential for COVID-19 transmission. Judge Zisman acknowledged that telephone or electronic access meant a lack of meaningful contact and bonding between parents and their young children. ${ }^{165}$ Although the court has the statutory authority to establish terms and conditions on access as deemed appropriate, ${ }^{166}$ the Society was given the broad discretion to determine the "nature, frequency, duration, location and level of supervision." ${ }^{\prime 67}$

Likewise in SMCYFS $v C B$, a supervision order was ruled out and an infant child was placed with a maternal aunt under a temporary order because the agency had no ability to monitor risks to the infant due to COVID. ${ }^{168}$ Here the mother had separated from an abusive partner but again, as is common with domestic violence survivors, was struggling with mental health issues and had been diagnosed with PTSD. ${ }^{169}$ The mother also lost in-person access to her older children who were in the care of the aunt because her access could not be supervised due to the closure of supervised access centres and the need to physically distance. While the Society was under an obligation to ensure meaningful access in alternative ways, and could provide electronic access to the older children, the court held that the health and safety of the mother, child, and access supervisor were more important than the loss of the mother's ability to bond with her infant through access. Again, the Society was given the discretion to review access on an ongoing basis and expand it when deemed safe as a result of COVID.

164. Ibid at para 126 .

165. Ibid at paras 156-57.

166. CYFSA, supra note 156, s 94(8).

167. CAS of Toronto, supra note 162 at para 160.

168. 2020 ONSC 2109.

169. See Mosoff et al, supra note 159. 
There are cases in which the Society's ability to monitor conditions under a supervision order or provide supports was not raised or questioned, ${ }^{170}$ and as of 8 May 2020 the Ontario policy that had suspended in-person access since mid-March was lifted. There are nonetheless questions as to whether Societies should have been given the blanket authority to determine how access was to be exercised or alternatively, whether courts should have undertaken an individualized assessment of the relative risks. Admittedly, there are risks to staff and foster families that must be considered in this context but by contrast with the assumptions made by courts in cases involving parenting orders, the child's exposure to persons across more than one household here appears to be presumptively problematic. Overall, the implications of COVID-19 for women experiencing domestic violence and facing removal of their children by child protection agencies have, in the short-term, been profound. Loss of the opportunity to parent under supervision or to maintain access with children in care can also potentially make it harder for mothers to regain care of the children in the longer term. Here we see a very different "planet" from the family law planet, where the importance of contact with fathers especially is de facto presumed.

\section{CRIMINAL}

The criminal response to intimate partner violence has evolved over the decades. Feminist and anti-violence activists in the 1980s focused on the gendered and public harms of domestic violence, but there has been increasing recognition that some reforms, such as pro-charging and pro-prosecution policies, disproportionately criminalize members of marginalized communities-including poor, racialized and Indigenous accused persons, and abused women trying to defend themselves

170. Children's Aid Society of Districts of Sudbury and Manitoulin v AH, 2020 ONSC 2704 [Children's Aid Society]. See also Protection de la jeunesse -201975, 2020 QCCQ 1814 [Protection de la jeunesse]. In Children's Aid Society, decided 30 April 2020, the children were allowed to remain in the mother's care subject to a supervision order with "numerous and stringent conditions" imposed by the lower court," (at para 63). The mother's condition had stabilized, and any risk of harm was described as speculative. Here too, the Society was able to determine how the father's supervised access was to be conducted. In Protection de la jeunesse, the progressive reintegration of a nine-year old child was not possible under the emergency conditions in Québec, so the child was returned to the mother with orders "that the child receive all health care and services, including any therapeutic service, required by his condition," as well as the services of an educator with access by the father supervised by the Director (at para 64). 
or their children from violence. ${ }^{171}$ At the same time, criminal laws may also be under-enforced in some communities-including Indigenous communitiesbecause police and other justice sector actors minimize or normalize gender-based violence. ${ }^{172}$ In the context of the COVID-19 pandemic, these concerns combine with the reality that over-crowded prisons are a breeding ground for the virus, placing inmates and staff at risk, as well as the reality that the social conditions associated with the pandemic, discussed above, place women at greater risk of violence. ${ }^{173}$ Criminal cases during the pandemic thus require a balancing of the rights of accused persons and complainants even more so than usual.

Our sample contained only fifteen relevant criminal cases, which is a relatively small number. However, the cases almost all deal with interim release (bail) or sentencing, allowing for some common issues to emerge in these areas. There was only one criminal case that reviewed whether a trial should proceed on an urgent basis, which raises concerns about delay in hearing criminal matters on the merits. ${ }^{174}$ Even cases that were to be heard by Domestic Violence Courts, which normally fast-track criminal intimate partner violence matters,

171. See e.g. Claire Houston, "How Feminist Theory Became (Criminal) Law: Tracing the Path to Mandatory Criminal Intervention in Domestic Violence Cases" (2014) 21 Mich J of Gender \& L 217; Leigh Goodmark, "Reframing Domestic Violence Law and Policy: An Anti-Essentialist Proposal" (2009) 31 Wash UJL \& Pol'y; Aya Gruber, "The Feminist War on Crime" (2007) 92 Iowa L Rev 741; Ananya Bhattacharjee, "Whose Safety? Women of Color and the Violence of Law Enforcement" (2001), online (pdf): <www.afsc.org/ sites/default/files/documents/whose\%20safety.pdf> [perma.cc/PH57-S8B6]; Dianne Martin \& Janet Mosher, "Unkept Promises: Experiences of Immigrant Women with the Neo-Criminalization of Wife Abuse" (1995) 8 CJWL 3.

172. See e.g. Reclaiming Power and Place: The Final Report of the National Inquiry into Missing and Murdered Indigenous Women and Girls (2019), online (pdf): <www.mmiwg-ffada. ca/wp-content/uploads/2019/06/Final_Report_Vol_1a-1.pdf> [perma.cc/6XF7-6CET]; Elizabeth Comack \& Gillian Balfour, The Power to Criminalize: Violence, Inequality and the Law (Fernwood, 2004) at 153.

173. See e.g. Jane Philpott \& Kim Pate, "Time running out to protect prisoners and prison staff from calamity” (31 March 2020), online: Policy Options <policyoptions.irpp.org/magazines/ march-2020/time-running-out-to-protect-prisoners-and-prison-staff-from-calamity> [perma.cc/2BHJ-3ER7].

174. See $R$ c Dallaire, 2020 QCCQ 1699 (finding that a trial should proceed urgently after reviewing a number of factors, including the possible reluctance of the Inuit victim to testify if there was further delay (at para 19)). 
have not been treated as necessarily "urgent" during the pandemic. ${ }^{175}$ Like the other areas of law we discuss in this article, given the time frame of our case law search, most of the reported criminal cases involved alleged offences that occurred pre-COVID-19. ${ }^{176}$ Not reflected here are the decisions made by other state actors, such as police and Crown prosecutors, about whether to charge or prosecute particular cases of intimate partner violence in light of COVID-19 considerations.

Although there is no specific offence of domestic violence in the Criminal Code, bail and sentencing are two areas of criminal law where there are explicit considerations for intimate partner violence. Interim release of an accused is normally assumed, based on the presumption of innocence, unless the Crown can prove that detention is necessary to ensure the attendance of the accused in court (primary grounds), for protection or safety of the public (secondary grounds), or to maintain public confidence in the administration of justice-which includes consideration of the gravity of, and the circumstances surrounding, the offence (tertiary grounds). ${ }^{177}$ Recent amendments to the Criminal Code require judges to consider whether the accused is charged with an offence in which "violence was used, threatened or attempted against their intimate partner" when deciding upon interim release. ${ }^{178}$ If so, and the accused was previously convicted of an offence related to intimate partner violence, the burden will be on them to show cause why they should be released. ${ }^{179}$ In cases involving sentencing, the presumption of innocence no longer applies, and courts must balance a range of objectives and principles. The abuse of an intimate partner is an aggravating factor and sentencing courts in cases involving intimate partner violence must

175. See Mattoo \& Butt, supra note 19 at 9. There was one case in our sample that was identified as being heard in Toronto's Integrated Domestic Violence Court (IDVC), but that was regarding a family matter involving access rather than a criminal matter. See Livingstone v Cooper, 2020 ONCJ 174. For a discussion of the IDVC, see Rachel Birnbaum, Michael Saini \& Nicholas Bala, "Canada’s First Integrated Domestic Violence Court: Examining Family and Criminal Court Outcomes at the Toronto IDVC" (2017) 32 J Fam Violence 621.

176. For an exception, see $R v$ Dagher, 2020 ONSC 2592 [Dagher] (accused charged with assault against his wife alleged to have occurred during COVID). See also the text accompanying notes 185, 193, and 203.

177. Criminal Code, RSC 1985, c C-46, s 515(10) [Criminal Code]. See also Rv St Cloud, 2015 SCC 27 [St Cloud].

178. Criminal Code, supra note 177, s 515(3)(a).

179. Ibid, s 515(6)(b.1) 
"consider the increased vulnerability of female persons who are victims, giving particular attention to the circumstances of Aboriginal female victims." ${ }^{180}$

In the bail and sentencing decisions during our timeframe, the urgency of hearing the matter was typically assumed. ${ }^{181}$ This is not surprising, considering that the person accused or found guilty in all of these cases was being detained in custody, and in-custody criminal matters were generally classified as urgent by courts across the country. ${ }^{182}$

$R v$ Mitchell is the only case in our sample where the court explicitly addressed the importance of not delaying the hearing of intimate partner violence cases during the COVID-19 pandemic. In his decision, Judge Gorman notes that the Provincial Court of Newfoundland and Labrador had recently announced that it would hear all matters that can be "efficiently and effectively presented for adjudication without the need for the physical presence of any person." In what was perhaps a subtle rebuke of the Crown, he stated: ${ }^{183}$

Victims of intimate violence are often very vulnerable and the Pandemic has increased their vulnerability. Cases involving intimate violence should not be placed on hold when the Court has the technology and has expressed a willingness to hear additional matters... There is no longer any reason for the Crown failing to bring matters forward. By delaying matters that can be heard, the Crown is denying access to justice for accused persons, complainants and victims.

The key issue in the reported criminal decisions is the extent to which courts balance any risk of contracting COVID-19 in jail with the risk of (further) harm to complainants. Courts have also been required to balance other concerns raised by the pandemic, such as trial delay or harsher incarceration conditions, with complainant safety concerns. These considerations can arise in several ways: (1)

180. Ibid, ss 718.2, 718.201. See also $s 718.3(8)$ (providing for increased sentences for subsequent intimate partner violence offences); ss 109(1)(a.1)(i), 109(2) (a mandatory weapons prohibition order for at least ten years in IPV cases).

181. For an exception, see $R v$ Cook, 2020 ONSC 2055 (bail hearing in midst of trial was found to be urgent, no decision on merits is available).

182. See e.g. Ontario Superior Court of Justice, "Consolidated Notice to the Profession, Litigants, Accused Persons, Public and the Media” (13 May 2020), online: <www.ontariocourts. ca/scj/notices-and-orders-covid-19/consolidated-notice/\#1_Urgent_Civil_and_Family_ Proceedings> [perma.cc/4B4L-U23M] (urgent criminal matters include: bail, bail review, detention review, guilty pleas, and sentencing for in-custody persons in urgent circumstances).

183. $R v$ Mitchell, 2020 CanLII 33884 [Mitchell] at paras 4, 5. 
in the review of grounds for release of the accused; ${ }^{184}$ (2) when an accused seeks review of an earlier bail decision based on a material change in circumstances, which — if proved - allows for a reconsideration of the primary, secondary, and tertiary grounds; ${ }^{185}$ and (3) in sentencing decisions, as relevant to the amount of credit for pre-trial custody that is seen as appropriate, or as otherwise relevant to the accused's sentence. ${ }^{186}$

Similar to the family law and child protection cases discussed above, courts have taken varying approaches to requiring actual evidence of the risks related to COVID-19 in both bail and sentencing decisions. This is a key concern in the intimate partner violence context. Because release of the accused may pose corresponding safety risks to the complainant and perhaps children, ${ }^{187}$ we might

184. See $R v$ Swierkot, 2020 QCCQ 1926 at paras 71-75 [Swierkot] (reverse onus case under s 515(6)(b.1), accused detained on all three grounds, COVID seen to have little impact because there were no specific concerns related to accused's health or prison in question); $R v$ Sangster, 2020 ONCA 332 [Sangster] (see the text accompanying notes 187, 200-201).

185. See Criminal Code, supra note 177, s 520; St Cloud, supra note 177 para 139. For cases where a material change was found, see $R v$ Fraser, 2020 ONSC 2045 [Fraser] (reasoning based on specific risk of COVID-19 at Ottawa Carleton Detention Centre, where accused was housed in dorm with ten to twelve people and was in remission from leukemia, he was nevertheless detained on the secondary ground given his "capability for significant violence... that ... is regularly directed toward women in his life" (at para 20)); Rv Medeiros, 2020 ONSC 2890 [Medeiros] (reasoning based on judicial notice of risks of contracting COVID-19 in prison and trial delay. The accused was detained on secondary grounds in light of his violent criminal record and concern for the safety of the complainant, even though the sentence would likely be less than time detained (at paras 12-13)); Dagher, supra note 176 (reasoning that COVID-19 was relevant to trial delay that would likely result in the accused being detained in pre-trial custody longer than any sentence he might receive (at para 20)). For a case where a material change based on COVID-19 was assumed, see $R v B T D, 2020$ NSSC $165[B T D]$ (the accused was detained on secondary and tertiary grounds (at para 25)). For cases where the Crown conceded a material change in circumstances based on COVID-19, see $R v$ Rajan, 2020 ONSC 2118 [Rajan] (see the text accompanying notes 190 to 194); $R v$ PS, 2020 ONSC 2186 [PS] (accused released on "very strict house arrest" with electronic monitoring (at para 8)).

186. See e.g. $R v O K, 2020$ ONCJ $189[O K]$ (reasoning the accused was to be given extra credit of 0.5 days for every day served during the COVID-19 crisis for "particularly harsh conditions" in the Toronto South Detention Centre (at para 41)); $R v$ Durance, 2020 ONCJ 236 [Durance] (reasoning that there would be no increase in credit for pre-trial custody, but sentence reduced based on worse experience of incarceration during COVID-19, although the amount of reduction unclear (at para 62)); Rv Studd, 2020 ONSC 2810 [Studd] (accused was at high risk for contracting COVID-19 and jail conditions were harsher than usual; sentence reduced by four months (at para 44)).

187. Children are rarely mentioned in the criminal cases. For exceptions, see Sangster, supra note 184 (noting that the accused and complainant have a child together, born while the accused was in custody); BTD, supra note 185 (noting involvement with child protection authorities). 
expect courts to require an evidentiary basis for the risks related to COVID-19. This expectation is fulfilled in several cases, where courts were not prepared to assume that the risk of contracting COVID-19 in prison was a significant consideration unless there was evidence the accused faced a specific risk because of health conditions and/or because of an outbreak in the facility in which they were or would be incarcerated. ${ }^{188}$

In other cases, courts were more willing to make assumptions about the risks to the accused, often taking judicial notice of the impact of COVID-19 in prisons. ${ }^{189}$ For example, in the much-cited case of $R v$ Rajan, the accused was charged with break, enter and commit assault, death threats, and criminal harassment in relation to several alleged incidents involving his former intimate partner. He was also charged with discharging a firearm into the complainant's home, where a bullet hole was found that matched a handgun discovered in his apartment pursuant to a search warrant. However, the gun was excluded from evidence at a pre-trial Charter application. In a bail review hearing, the Crown conceded that there was a material change in circumstances based on both the exclusion of the firearm and COVID-19, but sought to detain the accused based on the secondary grounds and concerns about the risk he posed towards the complainant. Justice Harris decided that while the charges against the accused were "troubling," the Crown's case was "substantially diminished" due to the exclusion of the firearm, and the risk to the complainant could be managed by releasing the accused with conditions to have no contact with her and to submit to house arrest (residing with his mother as surety) and electronic monitoring. ${ }^{190}$

On the tertiary grounds, Justice Harris discussed the risks of contracting COVID-19 in jail at some length, but for the most part this was based on general evidence rather than the specific risk to the accused, and discounted the Crown's evidence about the steps being taken to prevent the spread of COVID-19 in Ontario's correctional institutions. ${ }^{191}$ It is concerning how the consideration

188. See e.g Swierkot, supra note 184 at para 82; Fraser, supra note 185 at paras 13-14; Durance, supra note 186, paras 53-56.

189. See e.g. Medeiros, supra note 185 (judicial notice taken of the risks of contracting COVID-19 in prison); PS, supra note 185 (judicial notice taken of the risks of contracting COVID-19 for the accused with underlying health conditions).

190. Rajan, supra note 185 at paras 22, 23, 28-35. For other cases involving a consideration of electronic surveillance as a risk management tool, see Fraser, supra note 185; PS, supra note 185; Swierkot, supra note 184 . See also BTD, supra note 185 (discussing the new availability of electronic monitoring in Nova Scotia as of 1 May 2020, although it is unclear if this was a policy change due to COVID-19).

191. Rajan, supra note 185 at paras 36-74. The Court did note that the accused has an auto-immune disease (psoriasis) but this was not a major focus (ibid at para 63). 
of maintaining public confidence in the administration of justice weighs more heavily in favour of public concerns about a relatively abstract risk of the accused contracting COVID-19 in prison (though the court says this risk "is based on cold, hard scientific reality") rather than public concerns about the more concrete risks to the safety of the complainant, even without the handgun as evidence. ${ }^{192}$ The court's brief references to domestic violence reinforce the concerns noted above in the family law section about conceptualizing this violence primarily as discrete physical acts, as well as portraying the violence as a mutual problem. ${ }^{193}$ Moreover, the court's alarmist description of the COVID-19 pandemic-as dire, extraordinary, the virus as highly contagious, causing very serious illness or death-contrasts sharply with the muted attention given to the risk and harms of domestic violence. Justice Harris's conclusion that jail is "one of the most dangerous places imaginable"194 during the pandemic obfuscates the reality that the home, for victims of abuse, is far more dangerous than prison. While the COVID-19 pandemic is rendered as extraordinary and dangerous, the pandemic of violence against women is obscured, relegated to the mundane and common place.

In contrast, there are other cases where courts place more weight on the risks of intimate partner violence if the accused is released, ${ }^{195}$ but only one case where the increased risk of domestic violence due to COVID-19 is specifically addressed. In Mitchell, discussed above, Judge Gorman undertook a detailed

192. Rajan, supra note 185 at para 68.

193. Ibid (" $[\mathrm{d}]$ omestic relationships which go sour have a notorious tendency to engender violent emotions. The positive emotional bonds of affection and love when they are reversed can lead to acts of violence and aggression" at para 22). See also Dagher, supra note 176 (noting that the accused has no criminal record or history of "actual" violence (at paras 25-26)); PS, supra note 185 (where there is very little discussion of domestic violence or multiple breaches of no-contact orders, rather the focus is on the accused and the risk of COVID-19).

194. Rajan, supra note 185 at para 56.

195. BTD, supra note 185 (bail; noting that the accused has an unstable mental state in the presence of young children, bail denied but not related to COVID-19 risks (at para 124)); Fraser, supra note 185 (bail; noting that the accused "reflects a capability for significant violence ... regularly directed toward women in his life" but does not mention COVID-related risks of violence (at para 20)); Medeiros, supra note 185 (bail; expressing general concern for the safety of the complainant, and notes that the accused does not have a plan for where to reside if released (at para 40)); Durance, supra note 186 (rejecting conditional sentence based on the offender's "extensive history of disregard for court orders and violence" at paras 14,72); OK, supra note 186 (sentence; discussing, generally, the distribution of intimate images as form of abuse, control, and the degrading nature of other assaults (at paras 18-20)); Studd, supra note 186 (sentence; noting several aggravating factors regarding domestic violence but not related to COVID-19 (at paras 16-20)). 
analysis of the sentencing principles applicable to intimate partner violence cases, as well as the impact of COVID-19 on sentencing, noting in particular the risks to victim safety caused by the loss of shelter spaces due to the pandemic. ${ }^{196}$ The accused was sentenced to 180 days in jail with a one year period of probation, with the risk of contracting COVID-19 in jail found to be relevant to parole rather than sentence. ${ }^{197}$

Mitchell illustrates another issue in the decisions, namely the loss of services and supports due to COVID-19, which can impact the interests of both accused persons and complainants. Similar to the recognition of lack of shelter spaces for victims noted in Mitchell, in $R v$ Reimer, the British Columbia Court of Appeal noted that the presence of COVID-19 would "greatly restrict Mr. Reimer's ability to find accommodation" and removed a probation condition for advance approval of housing in his sentence appeal. ${ }^{198}$ On the protective side of the balance, the court upheld a condition for the accused not to publish any information about the complainant via the Internet or social media, and modified a condition designed to protect future intimate partners by requiring him to disclose his past criminal convictions to them. ${ }^{199}$ In $R v$ Sangster, a reverse onus case for bail pending appeal, the Court of Appeal for Ontario considered COVID-19 relevant to the public interest ground because the accused's convictions related to a "longstanding drug and alcohol addiction" that he had largely recovered from in custody, but there was now a lack of addiction counselling services available at his institution due to the pandemic. ${ }^{200}$ Although this was not seen as a decisive factor, the accused was released on bail pending his appeal of several convictions related to violence against his intimate partner, with whom he had reconciled and had a child. His release conditions included that he have no contact with the complainant without her "prior written orally revocable consent and in the presence of another adult." 201

196. Mitchell, supra note 183, at para 54, citing Rv Rich, [2020] NJ No 90 (PC) [Rich]. Judge Gorman noted that community-based sentences in cases of intimate partner violence can place victims at heightened risk given that access to "protection facilities for such victims can be effected (sic) by the Pandemic, potentially increasing their vulnerability" (ibid at 44). Rich is not included in our sample because it is not a case involving domestic violence.

197. Mitchell, supra note 183 at paras 55-56.

198. Rv Reimer, 2020 BCCA 102 at paras 92-94. Reimer had been convicted of several offences including "repeated and serious" threats against his ex-partner and breach of a no contact condition (ibid at para 60).

199. Ibid at paras 89,102 .

200. Sangster, supra note 184 at paras 46-47.

201. Ibid at para 19. 
Overall, we see an attempt on the part of courts in many cases to balance the COVID-related impacts of prison and the loss of services to accused persons/offenders with the safety of complainants/victims. However, apart from Mitchells attention to the loss of women's shelters, there is no discussion of the COVID-related risks of violence that have been raised in the literature, such as those connected to drug and alcohol abuse, unemployment, limited housing options and the likely pressures on complainants to take in an accused who has been released, notwithstanding no-contact conditions. To return to the concerns about criminalization noted at the outset of this section, there is also little mention of the marginalized circumstances of accused persons or victims in these cases, and how that might influence COVID-related risks. Surprisingly in light of the over-criminalization of Indigenous persons in Canada, there are no cases in our sample where the accused was identified as Indigenous. ${ }^{202}$ In the one case where it was noted that the accused was racialized, the court declined to take judicial notice that he was at higher risk of contracting COVID-19 in prison because he was of African descent, finding that this argument lacked a proper evidentiary foundation. ${ }^{203}$

\section{E. EMERGENCY PROTECTION ORDERS AND RESTRAINING ORDERS}

Among the key measures recommended by various international bodies to address the shadow pandemic is that states take measures to ensure women have meaningful access to EPOs. ${ }^{204}$ Most provinces and territories have domestic violence civil protection order legislation, which allows victims of family violence to obtain EPOs without notice to the other party in circumstances of urgency. Canadian jurisdictions differ in definitions of family violence, coverage

202. Our search did uncover Spotted Eagle, a sentencing decision that discusses violence against Indigenous women, but COVID-19 was only mentioned in passing as relevant to the court's pandemic-related procedures. See Rv Spotted Eagle, 2020 ABPC 70 [Spotted Eagle]. See also Dallaire, supra note 174 (involving an Inuit complainant).

203. Durance, supra note 186 at paras 53, 56. See also Dagher, supra note 176 (noting that the accused was originally from Lebanon, with no further discussion).

204. Human Rights Watch, supra note 23; United Nations Development Programme Brief, "Gender-Based Violence and COVID-19" (11 May 2020) at 3, online (pdf): <www.undp. org/content/undp/en/home/librarypage/womens-empowerment/gender-based-violenceand-covid-19.html> [perma.cc/C66S-YTQU] [United Nations Development Program]; United Nations Human Rights Office of the High Commissioner, News Release, "States must combat domestic violence in the context of COVID-19 lockdowns - UN rights expert" (27 March 2020), online: <www.ohchr.org/EN/NewsEvents/Pages/DisplayNews. aspx?NewsID=25749\&LangID=E $>$ [perma.cc/DJR2-6UM3] [UN Human Rights, "domestic violence in the context of COVID-19 lockdowns"]. 
of non-familial relationships, and application procedures. ${ }^{205}$ Alberta appears to be the only jurisdiction that changed its protection order procedures in response to COVID-19. As noted earlier, it provided legal aid duty counsel to assist applicants, including through an after-hours service. Alberta also allowed applications for EPOs to be made by victims via telecommunication during the pandemic, whereas previously they had to apply in person or have an authorized person apply on their behalf. ${ }^{206}$ There was some anecdotal evidence of confusion in implementing these changes, which calls into question the accessibility of protective orders; nevertheless, these were still positive government initiatives that should be explored as longer term policies. ${ }^{207}$ The change to allowing applications by telecommunication would also be consistent with EPO procedures in some other provinces, ${ }^{208}$ and is a good example of how the pandemic could provide impetus for broader reform to legal remedies for domestic violence. Accessibility of protective orders should be a goal of governments and courts in "normal" times and not just a pandemic-related benchmark.

Most provinces and territories with civil protection order legislation have procedures for review of EPOs, either on application by the claimant or respondent, or automatically within a certain period of time after the order was granted, with notice to the respondent. ${ }^{209} \mathrm{EPO}$ reviews were explicitly classified as "urgent" in some jurisdictions during the COVID-19 pandemic, and were

205. For a discussion see Koshan, Mosher \& Wiegers, "The Costs of Justice," supra note 7 at 13-14.

206. See Ministerial Order No 2020-011 (Community and Social Services) (April 7, 2020); Protection Against Family Violence Regulation, Alta Reg 80/1999, s 4 (previously allowing applications via telecommunication only by "designated persons" (e.g. peace officers and child protection workers)) and now allowing victims to apply by telecommunication.

207. For a relevant discussion, see Mark Cherrington, "Have to say, the Emergency Protection Order process during \#COVID19 in \#YEG has been a terrible experience. Mom calls to make an application, they tell her to go to court. I take mom to court, they tell us can't help \& to call. Now she is applying online. \#abpoli \#ableg" (21 May 2020, 18:45), online (Twitter): <twitter.com/MarkCherrington/status/1263601869139505152?s=20> [perma.cc/ GZ6H-U7PA] (exchanging with Sarah Eadie).

208. See e.g. Intimate Partner Violence Intervention Act, SNB 2017, c 5, s 3(2).

209. See e.g. Family Violence Protection Act, SNL 2005, c F-3.1, ss 9-10 [FVPA] (applicant and respondent can apply for variation or termination of EPO); Protection Against Family Violence Act, RSA 2000, c P-27 (PAFVA), s 2(6) (automatic review within nine working days of EPO). 
implicitly included in others. ${ }^{210}$ However, there is only one reported decision in this area during our timeframe, which may be in keeping with the pre-pandemic status quo, where EPO reviews are often disposed of without written reasons (and which, again, raises transparency and accountability concerns). ${ }^{211}$

The reported EPO review case, $M P v N J$, is interesting in the extent to which the COVID-19 pandemic is not discussed. ${ }^{212}$ In this case, a woman (NJ) had obtained a sixty-day EPO against her ex-partner (MP) in April 2020 that required that MP have no contact with her or their two children. The circumstances that supported the EPO were provided in a sworn application made by NJ's counsel, and included evidence of coercive controlling behaviour by MP before and during the pandemic. ${ }^{213}$ Judge Gorman of the Provincial Court of Newfoundland and Labrador — who also decided Mitchell, discussed above—allowed the respondent's application to set aside the EPO because the original evidence to support the order was deficient in that it did not include a sworn statement by the victim, as required under the relevant legislation. Based on the evidence adduced on the application to set aside the EPO-which included evidence from the father, but not the mother-Judge Gorman also wasn't satisfied that there were grounds for the EPO to continue in force. ${ }^{214}$ Similar to the family law cases discussed above, there was little acknowledgement of the difficulty of marshalling evidence during the pandemic - in this case, the challenge for lawyers to obtain sworn affidavits from their clients. Judge Gorman also downplayed the alleged domestic violence by stating that "obtaining of an emergency protection order should not become a substitute for resort to the family court for issues involving custody and access of children." ${ }^{215}$ While allegations that EPOs are used to gain an advantage in family

210. See e.g. Court of Queen's Bench of Alberta, "Master Order \#3 Relating To Court's Response To The Covid-19 Virus" (April 21, 2020), Appendix D, online (pdf): <www.albertacourts. ca/docs/default-source/qb/covid/master-order-3---covid-19---final.pdf?sfvrsn=c4c68280_8> [perma.cc/S3HV-TQGF] (listing EPO reviews explicitly as "Matters of Highest Priority Requiring Immediate Attention"); Supreme Court of Newfoundland and Labrador, "Notice to the Profession and General Public: Covid-19: Preventative Measures" (March 18, 2020), online: <court.nl.ca/supreme/pdf/2020\%2003\%2018\%20-\%20Notice\%20to\%20the\%20 Profession\%20-\%20COVID-19\%20Preventative\%20Measures.pdf> ("requests for urgent relief relating to the safety of a child or parent" included as "urgent and emergency family matters" at 4(4.1)(a)).

211. For a family law case that mentions an unreported EPO review, see $A M D$, supra note 94 at para 20 (resolving the matter with "mutual restraining orders").

212. 2020 CanLII 29335 (NL PC) [MP v NJ].

213. Ibid at paras 40-41. The behaviours included forbidding NJ from speaking to her family, contacting child protection authorities, and taking photos and videos of her home.

214. Ibid at paras 11, 14-15. See also FVPA, supra note 209, s 4(4).

215. MP v NJ, supra note 212 at para 62. 
law proceedings are not new, this sort of statement may dissuade victims from pursuing protective legal remedies during the pandemic or otherwise.

Ontario does not have civil protection order legislation, but it provides for restraining orders in family legislation. ${ }^{216}$ Restraining orders were classified as "urgent" by Ontario courts during the pandemic, and while there are twelve family law cases in our sample that discuss such orders, they were not the main issue in most of these cases. ${ }^{217}$

The one exception is Harrington $v$ Dennison, where the court dealt with an ex parte application for a restraining order by a woman whose ex-partner had been charged with several violent offences against her in February 2020. ${ }^{218}$ Although he was in custody, the applicant feared that he was about to be released, and sought a restraining order to protect herself and their sixteen-month-old child, as well as a police enforcement clause. Based on the applicant's sworn affidavit, Justice Madsen of the Ontario Superior Court of Justice found the matter to be urgent and granted the restraining order on a temporary without prejudice basis. The court does not discuss the alleged violence in much detail, perhaps because the allegations were serious and were said to have occurred while the applicant was holding the child. ${ }^{219}$

216. Family Law Act, RSO 1990, c F.3, s 46; Children's Law Reform Act, supra note 77. Neither does Québec have specific civil protection order legislation, but the Code of Civil Procedure, provides for protection orders in the context of violence more broadly. See Code of Civil Procedure, CQLR c C-25.01 [Code of Civil Procedure]. There were no relevant cases from Québec involving protection order issues during our timeframe.

217. See "COVID-19 Pandemic - Scheduling of Family Matters in the Ontario Court of Justice” (7 May 2020), online: Ontario Court of Justice <www.ontariocourts.ca/ocj/covid-19/ covid-19-family-matters-may7> [perma.cc/CNF5-HRJG] [Ontario Court of Justice, "Scheduling of Family Matters"]; Ontario Superior Court of Justice, "Consolidated Notice to the Profession," supra note 84. Both Ontario Court of Justice, "Scheduling of Family Matters" and Ontario Superior Court of Justice, "Consolidated Notice to the Profession" included restraining orders as urgent matters.

218. Harrington, supra note 154 . The offences included assault causing bodily harm, strangulation, assault, and a historical assault against the mother (ibid at para 6).

219. For a different result, see Amirzada, supra note 127 (dismissing the mother's request for a restraining order as there was a criminal no-contact order in place that was not likely to expire soon (at para 42)). 
The remainder of the cases involved restraining orders made by courts in their resolution (usually interim) of parenting time and access issues. ${ }^{220}$ In most of these cases, the focus is on mutually restraining the conduct of both parents rather than restraining the conduct of abusers, once again failing to recognize the impact of domestic violence on mothers and children and the increased risk factors for violence presented by COVID- 19 .

Although there are a greater number of cases involving restraining orders than those dealing with civil protection orders, there are nevertheless fewer reported cases than we might expect during the pandemic, and that is cause for concern. This is especially so for Alberta given the introduction by Legal Aid Alberta of new specialized and after-hours duty counsel services to respond to the increased demands for EPOs during COVID-19. It may also be the case that courts are not writing reasons for decision here, or that domestic violence survivors requiring protective orders are not coming to the courts during the pandemic — even though they clearly meet urgency criteria.

\section{CONCLUSION}

The COVID-19 pandemic quickly thrust the world into uncharted territory. It has garnered very significant global, national, and local attention and massive public resources. Its severe health consequences have led to bold measures, including emergency orders suspending all but essential services, the closing of borders (including borders internal to Canada), requirements of physical distancing outside of one's household, and in some instances, mandating individuals to remain in their homes. But the COVID-19 virus threatens more than the health of individuals. It has led to significant unemployment, economic vulnerability, the proliferation of xenophobic and racist discourses, and increased isolation. As we have detailed in Part I, above, it has also led to an increase in domestic violence, the shadow pandemic.

220. See Flesias, supra note 109 (restraining the parties from talking to their children about each other or the litigation); Masse, supra note 101; Berube, supra note 86 (restraining the parties from speaking negatively about each other); MPM $v A L M, 2020$ ONSC 1862 (restraining the parties from recording their interactions); CKMv LOS, 2020 BCPC 101; Amiri, supra note 126; Jordan v Steele, 2020 ONSC 2834; Soares, supra note 124; TP v CS, 2020 ONCJ 210 (restraining, generally, the parties from communicating except regarding children, or only allowing to communicate in writing). See also Triestino, Motion Ruling, supra note 97 (based on new criminal harassment charges, concerns from the Children's Aid Society, and breach of a 2018 restraining order, the father's in-person access was suspended). 
As noted in the Introduction, above, UN Secretary-General Guterres has called on all governments to put women's safety first as they respond to the COVID-19 pandemic. While by no means exhaustive of the measures necessary to ensure women's safety, meaningful access to the legal system is critically important in responding to this call and has been recommended by various international bodies. ${ }^{221}$ Our review of measures taken and judicial decisions rendered in the first six weeks of the COVID-19 pandemic reveals that while some positive measures were introduced by governments and court officials, survivors' access to the courts and to justice were hampered by a range of obstacles that existed long before COVID-19, as well as by some of the particular measures taken. As such, our review points to reforms that are needed not only to address the ongoing COVID-19 pandemic and the increase in domestic violence that is anticipated to exist well beyond the life of COVID-19, or to respond more effectively to future viral pandemics, but to ensure access to justice for women and children impacted by the ongoing pandemic of violence against women.

While the inclusion by courts across the country of matters related to the safety of a parent or child and access to protection or restraining orders in definitions of "urgency" was a positive development, our review of reported decisions points to a number of potential concerns. ${ }^{222}$ As we suggested above, the strict and narrow definition of urgency may have operated to dissuade lawyers and self-represented litigants from proceeding. ${ }^{223}$ In the decisions on urgency-as with other decisions reviewed-there is little evidence that knowledge of the shadow pandemic has infiltrated judicial decision making. The courts' approach to defining urgent matters as those that were immediate, imminent, material, and tangible aligns with an understanding of domestic violence as discrete incidents of physical violence, obscuring both the many tactics that coalesce into patterns of coercive control and the heightened risks associated with COVID-19. In the criminal law context, urgency was most often assessed in relation to judicial interim

221. See Human Rights Watch, supra note 23; United Nations Development Program, supra note 204; UN Human Rights, "domestic violence in the context of COVID-19 lockdowns," supra note 204.

222. We have noted during the course of our research that as directives have been updated or replaced, earlier versions are not available on court websites. For research and other purposes, it is important that these directives be archived and we are hopeful that courts may undertake this initiative.

223. As noted earlier, additional data is needed regarding the number of applications made, granted, and denied. In addition, qualitative research with lawyers and other frontline service providers would yield a more complete picture regarding the barriers to, and facilitators of, access to the courts during the COVID-19 pandemic. 
release; only the decision in Mitchell ${ }^{24}$ noted the increased risks of domestic violence during the COVID-19 pandemic and highlighted the importance of not delaying the hearing of charges in this context. ${ }^{225}$ The limited understanding of domestic violence and of COVID-related risks reflected in these decisions points to the need to deepen the education of judges and lawyers. This need for education has been identified by many others prior to COVID-19; ${ }^{226}$ our review both echoes these prior calls for domestic violence education and expands the scope of such education to include awareness of the increased risks and changing tactics associated not only with COVID-19 but other major calamities that produce economic and social stressors.

In the family law and protection order contexts, procedural complexity may also have operated to limit access to protection orders and other remedies. And while access to legal representation is important in virtually all family law matters involving domestic violence, the increased complexity of urgency motions, the rapid pace of change, and the challenges of remote participation all point to an acute and heightened need for access to representation. As discussed above, provinces and territories differed markedly on this score, with some legal aid plans-Ontario's most notably_-moving quickly to enhance access, while others made no changes at all.

Judicial decision making and the safety of women and children were also hampered by the limited availability of other services. Limited access to medical, counselling, mental health, and other services during COVID-19 negatively impacted women's ability to prove domestic violence to the satisfaction of decision makers. This suggests that which services are deemed "essential" may need to be reconsidered with these issues of "proof" in mind, but also that judges may need to alter their approach, particularly in the family law context and on interim motions, to consistently err on the side of protection rather than

224. Supra note 183.

225. Other important data to gather, as noted earlier, relates to police and prosecutorial decision making during COVID-19. A particular issue related to service suspension arises in the context of domestic violence courts and the heavy reliance on outcomes such as Ontario's Partner Assault Response program.

226. See e.g. Law Commission of Ontario, Curriculum Modules in Ontario Law Schools: A Framework for Teaching About Violence Against Women, (Toronto, August 2012), online (pdf): <www.lco-cdo.org/wp-content/uploads/2012/10/violence-against-women-modulesfinal-report.pdf> [perma.cc/5KWA-DJND]; Luke's Place, "What You Don't Know Can Hurt You: The importance of family violence screening tools for family law practitioners" (Department of Justice Canada, February, 2019), online (pdf): <www.justice.gc.ca/eng/ rp-pr/jr/can-peut/can-peut.pdf> [perma.cc/24H5-RMP8]. See also Neilson, Responding to Domestic Violence, supra note 79. Neilson's book was originally a bench book for judges and is an excellent resource. 
parental access where credible evidence of risk is brought forward. We also hasten to point out that while there are no doubt issues of concern regarding proof of domestic violence that are COVID-19 specific, the systematic discounting of the credibility of women survivors of domestic violence within the justice system has been a longstanding matter of concern. ${ }^{227}$

The lack of access to services impacted judicial decision making in other ways as well, often limiting the outcomes available. For example, the lack of services in the child welfare context had the effect of severing parental access to children in care; the lack of housing alternatives for an accused on judicial interim release impacted conditions that could be attached to release; and the closure of supervised access centres resulted in a less protective form of supervision (that is, supervision provided by family members). Here too, while the lack of services was certainly heightened during the time period of our review, it has been a matter of ongoing concern. And here too, it is important to consider which services are deemed essential. Importantly, across the country violence against women shelters were deemed essential, but other services—supervised access, child welfare supervision and supports - are among others that are critical to the safety of women and children and ought to be characterized as "essential."

As we noted at the outset, while there are similarities in approaches across the areas of law examined, there are also some significant differences. The family law context, we have argued, is driven by normative commitments to maintaining a child's contact with both parents and to privatized, individualized resolution of disagreements. These deeply entrenched commitments—which are also seen in the protection order context-have served to obfuscate the risks of both COVID-19 and domestic violence. In the child welfare context, mothers are expected to protect their children from abusive fathers, shifting responsibility to mothers alone to ensure the father has no contact (or only that contact permitted by child welfare authorities). Given the over-representation of Indigenous and African-Canadian children in care, the mothers who are responsibilized ${ }^{228}$ are

227. See e.g. Deborah Epstein \& Lisa A Goodman, "Discounting Women: Doubting Domestic Violence Survivors' Credibility and Dismissing Their Experiences” (2019) 167 U Pa L Rev 399.

228. We use the term "responsibilized" here in a manner consistent with the literature on neo-liberalism to capture the withdrawal of the state's role in the provision of a range of social and other services and the accompanying expectation of individual (or in some instances, familial) responsibility. See e.g. Andrew Woolford \& Amanda Nelund, "The Responsibilities of the Poor: Performing Neoliberal Citizenship within the Bureaucratic Field" (2013) 87 Soc Service Rev 292; John Clark, "New Labour's Citizens: Activated, Empowered, Resonsibilized, Abandoned?” (2005) 25 Critical Soc Pol'y 447; Brenda Cossman \& Judy Fudge, eds, Privatization, Law, and The Challenge to Feminism (University of Toronto Press, 2002). 
those who experience profound poverty and social marginalization. Although there are only a small number of reported cases that we draw from, they suggest a readiness to suspend access and the services necessary to ensure birth parents have meaningful involvement in their children's lives. The claims of mothers in the child welfare context hardly register, especially in comparison to those of fathers in the family law context (including those fathers charged with domestic assaults). In the child welfare context, the risks associated with COVID-19 were regarded as sufficiently serious to categorically deny birth parents ongoing in-person contact with their children. In the family law context, by contrast, father's claims to access were often regarded as "urgent," warranting the courts' attention and individualized assessments of risk, in which, as noted, the risks of both COVID-19 and domestic violence were downplayed. Many of the criminal law decisions share with the child welfare decisions grave concern about the transmission of COVID-19-in this case, in prisons. Judges in some of the decisions are hyper-focused on the dangers COVID-19 poses and their assessment of the tertiary ground in particular shows a pre-occupation with the risks to the accused or offender at the expense of complainants. Other decisions, by contrast, show more careful calibration of the risks of COVID-19 and of domestic violence.

Hester invoked the notion of the three planets to describe the domains of domestic violence work, child protection work, and child contact work; domains that roughly align with criminal, child welfare, and family law. She has argued that the tensions and contradictions between these domains inhibit the safety of women and children. ${ }^{229}$ Other work in the Canadian context has advanced a similar analysis. ${ }^{230}$ Here too then, while the tensions and contradictions we have highlighted in these cases are particular to the COVID-19 context, they reflect deeply engrained differences in values and approaches that undermine women's safety, as well as their access to justice.

229. Hester, supra note 8.

230. See Koshan, Mosher \& Wiegers, "The Costs of Justice," supra note 7; Janet Mosher, "Grounding Access to Justice Theory and Practice in the Experiences of Women Abused by Their Intimate Partners," (2015) 32 Windsor YB Access Just 149; Mary Ellen Turpel-Lafond, Honouring Kaitlynne, Max and Cordon: Make Their Voices Heard Now (Office of the Representative for Children and Youth, 2012), online (pdf): <www.clwk.ca/ wp-content/uploads/buddyshared/honouring_kaitlynne.pdf> [perma.cc/9WPU-28L7]; Federal-Provincial-Territorial Ad Hoc Working Group on Family Violence, "Making the Links in Family Violence Cases: Collaboration among the Family, Child Protection and Criminal Justice Systems" (Department of Justice, 2013). 
Our assessment of Canada's response to COVID-19 suggests that there is much that needs to change going forward as lawyers, court administrators, and judges continue to grapple with violence perpetrated against women in the on-going and post-pandemic context. But perhaps most significantly, it underscores just how poorly we have fared in addressing the pre-existing pandemic of violence against women: too limited of an understanding of its complexity, too little attention to the global (and particular) scale of its harms, and too few resources to address it. But it does not have to be this way: ${ }^{231}$

A pandemic amplifies and heightens all existing inequalities. Gender inequality plagued societies long before COVID-19, but it doesn't have to define the response to it. Some will argue that we can't focus on gender equality now. Others will say that it can wait until after crisis. But that's a false choice, as it is a mistake to see them as wholly separate. Instead, the pandemic you know well is accelerating the one that you also live with, even if you can't always see it.

The answer to improving the health of our societies and the health of our global population is the same: "Put women and girls at the center of efforts to recover from COVID-19.” 
